\title{
The separation and reunification of Germany: Rethinking a natural experiment interpretation of the enduring effects of communism
}

Citation for published version (APA):

Becker, S. O., Mergele, L., \& Woessmann, L. (2020). The separation and reunification of Germany: Rethinking a natural experiment interpretation of the enduring effects of communism. Maastricht University, Graduate School of Business and Economics. GSBE Research Memoranda No. 009 https://doi.org/10.26481/umagsb.2020009

Document status and date:

Published: 16/03/2020

DOI:

10.26481/umagsb.2020009

Document Version:

Publisher's PDF, also known as Version of record

\section{Please check the document version of this publication:}

- A submitted manuscript is the version of the article upon submission and before peer-review. There can be important differences between the submitted version and the official published version of record. People interested in the research are advised to contact the author for the final version of the publication, or visit the DOI to the publisher's website.

- The final author version and the galley proof are versions of the publication after peer review.

- The final published version features the final layout of the paper including the volume, issue and page numbers.

Link to publication

\footnotetext{
General rights rights.

- You may freely distribute the URL identifying the publication in the public portal. please follow below link for the End User Agreement:

www.umlib.nl/taverne-license

Take down policy

If you believe that this document breaches copyright please contact us at:

repository@maastrichtuniversity.nl

providing details and we will investigate your claim.
}

Copyright and moral rights for the publications made accessible in the public portal are retained by the authors and/or other copyright owners and it is a condition of accessing publications that users recognise and abide by the legal requirements associated with these

- Users may download and print one copy of any publication from the public portal for the purpose of private study or research.

- You may not further distribute the material or use it for any profit-making activity or commercial gain

If the publication is distributed under the terms of Article $25 \mathrm{fa}$ of the Dutch Copyright Act, indicated by the "Taverne" license above, 
Sascha O. Becker, Lukas Mergele, Ludger Woessmann

The Seperation and Reunification of Germany: Rethinking a Natural Experiment Interpretation of the Enduring Effects of Communism

RM/20/009

\section{GSBE}

Maastricht University School of Business and Economics 


\title{
The Separation and Reunification of Germany: Rethinking a Natural Experiment Interpretation of the Enduring Effects of Communism*
}

\author{
Sascha O. Becker, Lukas Mergele, and Ludger Woessmann ${ }^{\dagger}$
}

\begin{abstract}
German separation in 1949 into a communist East and a capitalist West and their reunification in 1990 are commonly described as a natural experiment to study the enduring effects of communism. We show in three steps that the populations in East and West Germany were far from being randomly selected treatment and control groups. First, the later border is already visible in many socio-economic characteristics in pre-World War II data. Second, World War II and the subsequent occupying forces affected East and West differently. Third, a selective fifth of the population fled from East to West Germany before the building of the Wall in 1961. In light of our findings, we propose a more cautious interpretation of the extensive literature on the enduring effects of communist systems on economic outcomes, political preferences, cultural traits, and gender roles.
\end{abstract}

Keywords: political systems, communism, preferences, culture, Germany

JEL classification: D72, H11, P26, P36, N44

February 22, 2020

\footnotetext{
* Our particular gratitude goes to Oliver Falck, with whom we started this project long ago and who provided continued support throughout. We also thank the four editors-Enrico Moretti, Gordon Hanson, Heidi Williams, and Timothy Taylor - for extensive comments. Discussion and comments from Davide Cantoni, Fredrik Carlsen, Nicola Fuchs-Schündeln, Oded Galor, Ulrich Glogowsky, Peter Gourevitch, Moshe Hazan, Sebastian Klüsener, Kjell Erik Lommerud, Rocco Macchiavello, Omer Moav, Markus Pannenberg, Jared Rubin, André Steiner, Joachim Voth, Romain Wacziarg, Felix Weinhardt, Niko Wolf, Chris Woodruff, Michael Wyrwich, and seminar participants in Trondheim, Bergen, Warwick, and San Diego in 2012, the Warwick Summer Workshop in Economic Growth 2014, and the Workshop on Institutions, Culture, and Long-Run Development 2015 at the Center for Advanced Studies in Munich are gratefully acknowledged. We would like to thank Ulrich Blum, Lucian Hölscher, Sebastian Klüsener, Thomas Rahlf, and Michael Wyrwich for providing data. Christoph Albert and Laurenz Detsch provided capable research assistance. Support by the competitive procedure of the Leibniz Association, the German Science Foundation (CRC TRR 190), and the Fritz Thyssen Foundation is gratefully acknowledged.

† Becker: Monash University, University of Warwick; CEPR, CESifo, IZA, CAGE, and ROA; sascha.becker@monash.edu. Mergele: ifo Institute at the University of Munich; CESifo; mergele@ifo.de. Woessmann: University of Munich and ifo Institute; CESifo, IZA, CAGE, and ROA; woessmann@ifo.de.
} 
German separation in 1949 into the German Democratic Republic and the Federal Republic of Germany and its reunification in 1990 seem to offer a unique setting of a rather unexpected introduction and termination of a communist regime in one part of a previously and afterward unified country. Analyzing East-West differences in Germany provides the opportunity to study effects of living in different political systems, which has general relevance for our understanding of the fundamentals of economic preferences and behavior. This paper shows that because of pre-existing differences and early selective migration, German division and reunification do not provide a straightforward case of a natural experiment. Taking these challenges into account, it summarizes what can be learned from the literature that studies how individuals who lived in East and West Germany differed at reunification and how these differences have evolved since then.

Under the communist regime, economic and general well-being of the East German population fell far behind the development in the West, as shown in Figure 1. While it is impossible to estimate a precise causal effect of communism on economic prosperity and personal freedom, it is clear that by the end of the 1980s, people in the West were immensely better off in terms of GDP per capita and life expectancy. ${ }^{1}$ Maybe more surprisingly, while life expectancy in the East has converged quickly to the Western level after reunification, the convergence of economic activity has stalled after an initial surge-despite continuing major transfers from West to East. Many scholars of transition economics had expected that changing the system would suffice to ensure convergence, as undoing the artificial distortions that central planning imposed on the economy would let it return to its natural market orientation. Initial decisions about converting East German marks at 1:1 parity, how to carry out privatization, and other policy choices may have contributed to the path of East German economic activity after reunification. But a growing literature emphasizes that living under communism may have changed people's attitudes and preferences more deeply, giving rise to much more enduring effects even after the end of the political regime-and suggesting that transitions are about more than removing policy distortions.

Still, even though East Germans were unlikely to anticipate that their choices under communism might be suboptimal under an alternative regime, learning about the effects of communism based on the experience of German division and reunification poses unique challenges. To be considered a natural experiment, the exposure to different political systems

\footnotetext{
${ }^{1}$ GDP estimates for the communist East should be interpreted with care because the lack of market prices makes well-founded GDP calculation impossible and because of potential misreporting.
} 
would have to be unrelated to any other characteristics of the population that may be related to the outcomes of interest.

In the first sections of this paper, we highlight several sources of endogeneity that would violate the interpretation of the differential exposure to political systems as natural experiments. First, the drawing of the border between East and West Germany was not random. We demonstrate that substantial differences in economic structures, political preferences, cultural traits, and gender roles between what later became East and West Germany existed well before World War II. Second, East and West Germany were differentially affected by the war and by the dismantling of infrastructure and reparations to the occupying forces in the immediate afterwar period. Third, roughly one-fifth of the East German population moved to West Germany between 1945 and the building of the Berlin Wall in 1961, and this out-migration was likely selective with respect to political and economic preferences. Prior literature considers some of these aspects but tends to miss important pre-existing differences by using rough measures or by aggregating data that combine the area of what would later become the German Democratic Republic with areas that would be part of Poland. For this paper, we collect fine-grained data on a broad series of indicators at the county level that allow us to provide a clearer picture of pre-existing differences. Together, this evidence suggests that we might expect substantial differences in attitudes between individuals who lived in East and in West Germany even in the absence of differential exposure to political systems.

We then turn to an overview of the available evidence about Germany's experience of separation and reunification on enduring differences in economic outcomes, political attitudes, cultural traits, and gender roles. We do not attempt a formal reworking of any of this literature, but instead focus on whether the central results of various studies are likely to have an upward or downward bias when aspects of pre-existing historical differences, differential treatment during World War II and the occupation period, and German-German migration before the Berlin Wall are taken into account.

Our discussion also suggests a broader lesson beyond the effects of German reunification. There is a wide literature exploring how political systems persistently affect the economy and population preferences, with a particular focus on different legacies between capitalist and socialist societies (for a review, see Simpser et al. 2018). Studies examining a major political event, like the arrival or departure of communism or other forms of autocracy, might face similar challenges when interpreting the before-and-after differences as a natural experiment. The ways in which borders were originally drawn, events that took place during the transition, and patterns of in- or out-migration are often important. Thus, we are proposing 
the need for a reinterpretation of the existing literature on the "effects" of communism and call for a closer consideration of the formation of political systems more generally.

\section{Pre-existing Differences between East and West Germany}

\section{Historical Background: How the Border Got Drawn}

The location of the border between the German Democratic Republic (GDR) and the Federal Republic of Germany (FRG) is not the random outcome of where American, British, and Soviet tanks stopped at the end of World War II in 1945. Instead, in anticipation of the defeat of Nazi Germany, the foreign ministers of the United States, United Kingdom, and Soviet Union agreed on the formation of the European Advisory Commission at the Moscow Conference on October 30, 1943, which was confirmed at the Tehran Conference in November. The commission was asked to explore the political framework for postwar Europe and to make recommendations to the three governments (Kowalski 1971).

Based on the recommendations of the European Advisory Commission, the post-World War II border between East and West Germany was agreed upon in the so-called London Protocol, signed on September 12, 1944. The American, British, and Soviet armies were each allocated a zone of occupation of roughly equal population size. Berlin was to be jointly occupied. Two changes were made later: First, an additional French zone was carved out of the American and British zones. Second, parts of the Soviet zone were given to Poland (so that the Soviet-Polish border followed the "Oder-Neisse line"), and Poland became a Soviet satellite country. Neither change affected the German-German border, which separated the Soviet zone from those of the Western allies.

Figure 2 shows that the border between the Soviet and the Western occupation zones followed the pre-World War II borders of states of the German Empire and provinces of the largest state of Prussia (with a few very minor exceptions for geographic connectedness). ${ }^{2}$ As a result, the German-German border separated the populations of pre-existing regions with distinct histories and cultures. The British delegation to the European Advisory Commission argued that this approach allowed to "encourage rather than [...] prejudice any separatist or particularist tendencies,” providing a safeguard against a revival of the former German state (Foreign Relations of the United States 1968, pp. 150ff). The border thus was entirely different

\footnotetext{
2 The minor exceptions where post-World War II borders deviated from pre-war province or state borders are marginal areas near Ratzeburg, Amt Neuhaus where no bridge crossed the river Elbe, the Hessian county Herrschaft Schmalkalden, and the Eastern bit of county Blankenburg. All these areas risked isolation in their original zone of occupation and were exchanged between zones to facilitate connectivity with their neighborhood.
} 
from the end-of-war frontline between the Red Army and the US and British armies. Indeed, by May 1945 the Western armies had already pushed deeply into what later became East German territory, but handed over control to the Soviets once German defeat was accomplished, thereby honoring the agreement made in the London Protocol. In 1949, the Soviet occupation zone became the German Democratic Republic, and the Allied occupation zones became the Federal Republic of Germany.

Given that the border between East and West Germany was a deliberate choice and followed pre-existing provincial boundaries, the populations living in the two parts may have differed already before the advent of communism in the East. Analyzing pre-World War II data for counties of what would later become the German Democratic Republic and the Federal Republic of Germany, we find important pre-existing East-West differences in several measures of economic outcomes, political preferences, culture, and gender roles.

\section{Economic Outcomes}

To investigate whether East-West differences in economic structures predate the division into East and West Germany, we draw on data from the 1925 German Census compiled by Falter and Hänisch (1990) (see also Hänisch 1989). Restricting the analysis to what would later be East and West Germany, the county-level data allow us to compare 202 counties in the East to 652 counties in the West. Figure 3 illustrates that the working-class structure of the GDR population predates its existence: The East-West border is apparent already before World War II, with the working-class share substantially higher in what would later become the GDR.

Using these data in regression analyses, the first entry in the first row of Table 1 shows that the share of blue-collar workers in the total labor force in the West was 35.6 percent. ${ }^{3}$ The second row shows that this share was 11.8 percentage points higher in the counties that would later become part of East Germany. In addition, the working-class share jumps abruptly in several regions around the later inner-German border, especially in the southwest and the south of what later becomes East Germany. As shown in the remaining columns of Table 1, the difference in working-class shares is just as apparent when focusing on the 468 counties within 200 kilometers of the later border or the 244 counties within 100 kilometers of the later border

\footnotetext{
${ }^{3}$ The numbers in Table 1 are based on a series of separate regressions, using county-level data. For details on these regressions, see the online Appendix available with this paper at the JEP website. For additional results and more detail on pre-existing differences between East and West Germany, see Table A1 and Figures A1-A4 in the Appendix. While the inner-German border provides a clean separation of pre-World War II counties into East and West Germany (as discussed above), several pre-World War II counties straddled across both sides of the Oder and Neisse rivers that formed the later GDR-Polish border. We include all those counties in our analysis whose county capital is part of the later East Germany. Berlin is excluded from the analysis throughout.
} 
(analyses that also entail a more balanced number of counties on either side of the border). A difference of 7.3 percentage points even shows up when narrowing the analysis to only those 59 counties that have a direct contact with the later border. ${ }^{4}$

The difference in occupational structure is also reflected in the sectoral composition of the economy, where the employment share in manufacturing (industry and crafts) is 8.3 percentage points larger in the Eastern compared to Western counties of Germany, where it was 35.7 percentage points. When restricting the analysis to counties within 100 or 200 kilometers of the later border, the difference is even larger at more than 11 percentage points. The larger manufacturing share in East Germany mirrors the reverse pattern in the agricultural sector. While the agricultural employment share was 35.2 percent in the West, it was only 22.4 percent in the East. By contrast, there are hardly any East-West differences in average employment shares in sectors reflecting basic services such as administration, domestic services, and the health sector. For example, health-sector employment shares do not differ significantly between counties in the East and the West.

Given the important difference between planned and market economies in allowing for entrepreneurship and self-employment, the literature on contemporaneous East-West differences places a strong focus on these outcomes. However, the self-employment share was substantially lower in the East than in the West already in 1925 (Fritsch and Wyrwich 2014). As shown in Table 1, the difference is 8.4 percentage points on average and endures when focusing on counties closer to the later border.

The pervasive differences in economic structure are consistent with an analysis of trade flows between different parts of the country. Wolf (2009) shows that the German Empire was a poorly integrated economy before 1914 and (only) "reasonably well integrated" by the end of the Weimar Republic.

\section{Political Preferences}

To analyze pre-existing political preferences, a natural starting point is to look at vote shares for the Communist Party of Germany (Kommunistische Partei Deutschlands, KPD) before World War II. During the Weimar Republic (1918-1933), regular elections for the Reichstag were held throughout Germany. We study county-level data on vote shares of

\footnotetext{
${ }^{4}$ These discontinuous differences around what would later become the GDR border indicate that even spatial regression discontinuity designs around the East-West border may be affected by pre-existing heterogeneity.
} 
different parties in the national Reichstag election of December $1924 .{ }^{5}$ The second panel of Table 1 illustrates that counties that would later become part of East Germany have a communist vote share that is 4.9 percentage points higher compared to the West's 5.0 percent, and thus nearly twice as high. This difference is even larger, at close to 7 percentage points, when focusing on the counties within 100 or 200 kilometers of the later border.

The East-West difference is even larger when considering all left-wing parties, which include the much larger Social Democratic Party (Sozialdemokratische Partei Deutschlands, SPD) in addition to the KPD, as well as the negligible USPD. In the West, 25.4 percent of voters supported these parties, while the left-party vote share was 15.2 percentage points larger in the East, totaling 40.6 percent. ${ }^{6}$ The stronger support for communist and left-wing parties is likely linked to the larger working-class and manufacturing shares indicated above.

Clearly, studies looking at Germany’s separation and reunification cannot implicitly assume that the regions-or even the areas relatively close to the border-were originally similar in their political leanings. Results for vote shares of other political parties indicate that the larger preferences for left-wing parties in the East come largely at the detriment of vote shares for the Catholic center-right Zentrum party. This relates to the fact that the Zentrum party was the focal party of Catholics in Germany, and since counties in the East were predominantly Protestant (as discussed next), Zentrum had lower vote shares in those areas. The electoral data also reveal that East and West varied in voter turnout, which was 5 percentage points higher in the East. This difference disappears, however, when restricting the analysis to counties within 100 kilometers of the later East German border.

\section{Culture}

One dimension of cultural differences that is available in historical census data is religious denomination. The share of Protestants was higher in the East than in the West, which partly reflects that Martin Luther's city of Wittenberg is situated in the middle of what would become East Germany (Becker and Woessmann 2009). In the 1925 German census, 91 percent of the population in the Eastern counties was Protestant, compared to only 49 percent in the Western counties, as shown in the third panel of Table 1 . The difference becomes smaller when

\footnotetext{
${ }^{5}$ The December 1924 election provides an informative example as it took place after the establishment of the Weimar electoral system but before the rise of National Socialism, which disrupted the existing party system by becoming the first "mass-integration party" (for example, Falter 2014). Still, we find qualitatively similar results for other elections such as May 1924 and May 1928.

${ }^{6}$ In the May 1924 election, the East-West differences are even larger at 7.4 percentage points (around 10 percentage points in the border subsamples) for the communist vote share and 19.7 percentage points for the left vote share (not shown).
} 
zooming in on counties situated closer to one another, but it is still 24.0 percentage points in the sample of counties within 100 kilometers of what later became the German-German border. ${ }^{7}$

Echoing the larger Protestant share, the share of Catholics in the East was 43.8 percentage points smaller compared to the 49.1 percent in the West. The share of Jewish population was slightly but significantly lower in the East, albeit at a very low level of 0.2 percent compared to 0.5 percent in the West. However, Berlin-which had by far the largest Jewish community in the German Empire but was divided between East and West—is excluded in this analysis.

Beyond denominational affiliation, statistical surveys of the Protestant Regional Churches of Germany on the "Expressions of Churchly Life" provide an historically unique indicator of church attendance. Based on headcounts combined in Sacrament Statistics (Abendmahlsstatistik), the measure refers to the number of participations in Holy Communion relative to the number of Protestants, which was used by contemporaries as a proxy for churchliness (see also Becker and Woessmann 2013, 2018; Becker et al. 2017). We follow Hölscher (2001), who gathered the data at the level of church districts (Kirchenkreise) from regional archives and focuses on the year 1910 because of broad data coverage, but we use the average of the data available for the years 1900-1910 to reduce measurement error.

Church attendance at this time was substantially lower to the East of what later became the East German border. As shown in Table 1, participations in Holy Communion were 16.3 percentage points lower among East German Protestants, compared to an average of 55.4 percent among West German Protestants. This difference is robust in the smaller bands around the border and holds even for the counties contiguous to the border. Hölscher (2001, p. 7) notes: “A look at the map of Protestant Communion participation in 1910 [...] already reveals the later German dividing border before the First World War between Hesse and Thuringia. This suggests the conjecture that [...] in large parts of East Germany it was not the socialist regime that first eroded and undermined ecclesiastical life, but rather that, conversely, an already older unchurchliness in these regions paved the way for the reception of socialist [...] convictions.”

\section{Gender Roles}

With respect to gender roles in the labor market, the 1925 census provides employment statistics by gender. Wyrwich (2019) presents county-level data on female labor-force participation, measured as the share of women registered as non-domestic employees within

\footnotetext{
${ }^{7}$ Grashoff (2019) notes that suicide rates during the Weimar Republic were also higher in the East, which he sees as a corollary of more widespread Protestantism (Becker and Woessmann 2018).
} 
the entire female population. As pointed out in Wyrwich (2017), participation of females in the formal labor market was higher on average in East relative to West Germany before World War II. At the 1925 county level, female labor-force participation was 6.0 percentage points higher in the East compared to the mean of Western counties of 32.5 percent, as shown in the fourth panel of Table 1. Again, the significant difference also emerges in the more geographically restricted samples. ${ }^{8}$

In addition, Klüsener and Goldstein (2016) have shown that East-West differences in family-formation behavior, as documented in extramarital births, predate the 1945 division of Germany. They provide data on extramarital birth ratios in 1937 published by the German Imperial Statistical Office, confirming that extramarital fertility was higher on average in the East. As shown in Table 1, the difference amounts to 3.3 percentage points on average, compared to the Western mean of 6.7 percent. This difference is also evident in the restricted samples.

Overall, our analysis documents remarkable historical differences in economic outcomes, political preferences, culture, and gender roles between the populations living in the regions that were to become East and West Germany. Well before World War II, people in the later East Germany were more likely to be working class and to work in manufacturing, less likely to be self-employed, and more favorable to communist and left-wing political parties. The East had higher Protestant shares, lower church attendance, higher female labor-force participation, and higher extramarital fertility. To the extent that such pre-existing differences persist through the communist period, they may well be an essential source of post-reunification heterogeneities between East and West Germans.

\section{Differential Affectedness by World War II and Occupying Forces}

A further source of East-West differences is the potentially differential effect of World War II itself on the different parts of Germany, as well as potential differences in the treatment received during the years 1945-1949, when East and West Germany were occupied by Soviet and Allied Western armies, respectively. Economic historians have long noted differences in labor productivity in manufacturing between East and West Germany predating World War II.

\footnotetext{
${ }^{8}$ Campa and Serafinelli (2019) find the opposite when using the ratio of women employed to total employed, which likely results from inclusion of the categories "work in household" and "family members who help out."
} 
Using the 1936 Manufacturing Census, van Ark (1996) shows that sales per employee in East Germany amounted to only 84 percent of the level in West Germany. ${ }^{9}$

In his comprehensive comparison of the East German and West German economies, Sleifer (2006) notes that after 1944, the East and West German industrial capital stocks showed a strongly divergent development. This is not the result of larger damage due to war activity, but largely attributed to the dismantling of East Germany's industrial capital stock by the Soviet Union. Baar et al. (1995) estimate that East Germans paid much more than West Germans (2,784 vs. 1,611 Reichsmarks per capita) in terms of total war damages, dismantling, reparations, and occupation costs (see Sleifer 2006, Table 4.3). The difference is mainly due to higher reparations (1,065 vs. 23 Reichsmarks per capita) and higher losses due to dismantling of capital equipment (384 vs. 60 Reichsmarks per capita) in the East. ${ }^{10}$

Overall, while the West German industrial capital stock in 1948 was higher than in 1936, the East German capital stock was at only 69 percent of its 1936 level (Sleifer 2006). Considering that the East German manufacturing sector was already at a disadvantage in 1936, this means that it had fallen significantly further behind by the time the German Democratic Republic was established.

Another indication of differences arising between East and West already before the German Democratic Republic and the Federal Republic of Germany were officially founded in 1949 can be seen when looking at sex ratios, computed as the number of men to women. We digitized county-level data from the German Census jointly administered in all four occupation zones on October 29, 1946. The sex ratios in the four occupation zones (excluding Berlin) were 0.820 in the American zone, 0.835 in the British zone, 0.790 in the French zone, and 0.743 in the Soviet zone. There had been no such differences in 1939, in the last pre-World War II census, when sex ratios varied only between 0.954 and 0.974 across the four areas. The larger decrease in sex ratios in the Soviet zone may reflect a combination of a larger fraction of war casualties as well as sex imbalances in very early East-West migration. Whatever the source, considering the well-known implications of imbalances in sex ratios for labor-market outcomes (for example, Angrist 2002), these differences might have contributed to differences in several outcomes of interest, such as female labor-force participation, gender roles, and even political outcomes.

\footnotetext{
${ }^{9}$ This lower productivity of the manufacturing sector counteracted the larger share of manufacturing in the East. Pre-World War II GDP per capita was not very different between West and East Germany (see Figure 1 above).

${ }^{10}$ War damages are actually lower in East Germany compared to the West (686 vs. 839 Reichsmarks per capita), and the costs of occupation are roughly similar (649 vs. 689 Reichsmarks per capita).
} 
Overall, war-related damages and differences between occupying forces in the Soviet and non-Soviet zones implied that the GDR was off to a worse start before the new states had a chance to develop their own identities.

\section{Selective Out-migration before the Berlin Wall}

\section{Historical Background: Out-migration between 1945 and 1961}

The Soviet Occupation Zone was established in East Germany right after the end of World War II in 1945, culminating in the foundation of the German Democratic Republic in 1949. Although the freedom of movement was restricted, the "iron curtain" was at first by no means impenetrable. Throughout the 1950s, people could move rather freely between the East and West sectors of Berlin, resulting in substantial East-West migration. These movements only ended with the construction of the Berlin Wall in 1961.

Statistics about migration from the Soviet Occupation Zone to the Western Occupation Zones during the years 1945-1949 are considered somewhat problematic. Plausible estimates from Heidemeyer (1994, Table 2) suggest that about 875,000 residents of the Soviet Occupation Zone moved to the Western Occupation Zones during the years 1944/45-1949. Statistics for the years 1950 to 1961 are considered more reliable. Van Melis (2006, Table 1) presents monthly statistics on migration from East Germany into West Berlin and West Germany between September 1950 and December 1961 that add up to 2.75 million East-West migrants. Comparing the estimated East-West migration over the entire 1945-1961 period to the roughly 18 million inhabitants in the Soviet Occupation Zone in 1946, about one-fifth of East Germany’s population migrated West until 1961, when the Iron Curtain was completed and East-West migration was all but shut down.

\section{Evidence on the Selectivity of East-to-West Migration}

The evidence on the selectivity of this East-West migration is suggestive, although not conclusive. Economic research suggests in general that migrants tend to be people who are more willing to take matters into their own hands than stayers, more entrepreneurial, and selected along other dimensions (for example, Borjas 1987; Grogger and Hanson 2011; Fairlie and Lofstrom 2015; Parey et al. 2017). More specifically, it seems likely that those who left the East for the West had less preference for a communist system and were more supportive of a capitalist one, on average. This applies to ordinary citizens and leading politicians alike. In 1945, the Christian-Democratic Union (CDU) - the party of Konrad Adenauer and Angela 
Merkel — was founded across all zones of occupation, including the Soviet one. In the first years after 1945, the CDU had several ministers in zone-wide or state-level governments in the East. However, all CDU ministers resigned (voluntarily or by force) and migrated to the West. The Soviet occupation forces and the later East German government also expropriated many large landowners and used de-Nazification to expel not only Nazis but also those they perceived as critical to communist rule (Jessen 1999).

Using West German datasets, we can compare some characteristics of those who moved from the East to the West with people who had always been in the West (see also Bauernschuster et al. 2012). Data from a retrospective survey in the German Microcensus 1971, which covers a representative 1 percent sample of the German population, allow us to compare characteristics of those individuals who left the Soviet Occupation Zone and then the GDR in its early days with local West Germans. Table 2 shows that early East-West movers were more likely than local West Germans to be white-collar workers (30.4 vs. 20.3 percent), civil servants (13.5 vs. 6.1 percent), or self-employed (10.1 vs. 7.2 percent). ${ }^{11}$ There is a related selection on education: early East-West movers were much more likely to have more than basic schooling (60.8 percent) than local West Germans (39.2 percent). Furthermore, Bauernschuster et al. (2012) present evidence from the German General Social Survey (ALLBUS) 1991-2004 showing that those who had left the East for the West before 1961 see a lesser role for the state than the original West Germans.

There is also some anecdotal evidence for selection on age, health, and family status. The president of the Statistical Office of the Soviet Occupation Zone (SBZ), Bruno Gleitze, remarked that "the Soviet Occupation Zone acted like a sieve, holding back the aged, sick and single” (“die SBZ [wirkte] wie ein Sieb, das Alte, Kranke und Alleinstehende zurückhielt”, cited according to Steiner 2013, p. 14).

Recently, Eder and Halla (2018) argue that a substantial part of East-West migration towards the end of World War II was due to concerns about the advancing Soviet Army. They suggest that the dominant motive of migration in those years was escaping physical assault by the Soviet army, not avoiding the socialist regime. Their evidence shows that these migrants are strongly positively selected on skills.

Together, these analyses indicate that individuals staying in East Germany differed from those who moved to the West in being less likely to be white-collar workers or self-employed, less educated, and probably more receptive to the communist doctrine. Furthermore, the large

\footnotetext{
${ }^{11}$ We are grateful to Oliver Falck for extensive support in producing this table.
} 
majority of emigrants from East Germany went to live in West Germany, as opposed to moving to a different country outside Germany, thus becoming part of the West in East-West comparisons. Therefore, any post-reunification differences observed between people who lived in the East and people who lived in the West may also be the result of this earlier pattern of selection, rather than just of living under a communist system in the German Democratic Republic.

\section{A Note on Selective West-to-East Migration}

About half a million people migrated from the West to the East before 1961. One prominent example is German chancellor Angela Merkel, who was born in Hamburg in 1954 and moved to East Germany as an infant when her father, a Lutheran clergyman, received a pastorate in Brandenburg. While there is no reliable data on the composition of the West-East migration, it seems likely that-in addition to return migrants-mostly individuals committed to (or at least tolerant of) the communist idea would have moved this way. Propaganda from the East German government named various motives for such migration, including young men trying to escape compulsory military service in the West or those not in agreement with the capitalist system.

We collected data showing that a considerable share of the Politburo members in the early German Democratic Republic had been born in the West. In the years 1949-1961-the years between the foundation of the German Democratic Republic and the construction of the Berlin Wall-the East German Politburo had 19 members in total. Of these, 10 were born in the territory of what later became East German area or in Berlin, three were born in areas outside the later East or West Germany, and six were born in what became West Germany. While some of these Politburo members had lived in Berlin before World War II, they deliberately selected into building the East German state. As a prominent example, Erich Honecker, born in the Saar area near the French border in what later became West Germany, joined the Politburo in 1958 and was the last leader of the German Democratic Republic when the Berlin Wall came down in 1989. Some of the most strongly convinced communists in the East came from the West.

\section{Re-interpreting Evidence on the Effects of Communism in Germany}

In light of our evidence for pre-existing East-West differences, differential effects of World War II and subsequent occupying forces, and selective East-West migration, the question arises whether the previous literature potentially over- or underestimates the effects of communism when this history is taken into account. Generally speaking, in cases where some 
of the differences in post-1989 outcomes reflect pre-existing differences, the true effect of living in East Germany will be smaller than previous studies suggest. Conversely, in cases where preexisting differences are of opposite sign to the ones found after communism, the true effect of communism may be even larger. When considering migration, it is important to ask whether it is selective with respect to the outcome of interest, because not all outcomes will be equally affected by concerns of selective migration. ${ }^{12}$ While encompassing analyses of these issues are generally missing in the literature, some papers make an explicit effort to take them into account.

In this section, we look at some of the rapidly expanding literature on German division and reunification, focusing again on the four domains of economic outcomes, political preferences, culture, and gender. Table 3 summarizes the papers we cover in terms of data, empirical approach, and results. We are not formally re-analyzing the previous work, but instead discuss how the interpretation of results might have to be adjusted in light of our findings of pre-existing differences and selective migration.

\section{Economic Outcomes}

In terms of overall economic outcomes, GDP and income per capita did not differ widely between East and West Germany before World War II (see Figure 1 and Alesina and FuchsSchündeln 2007). By the time the GDR collapsed, East German GDP per capita was less than half of that of West Germany (see Figure 1 and Sleifer 2006, Graph 3.1). After reunification, labor productivity in East Germany was at a third of the Western level, putting the East somewhere between Mexico and Chile. Most of the capital stock of the former GDR was obsolete or unusable for production in a market economy (Siebert 1991; Akerlof et al. 1991). The communist experiment had ended in economic failure.

How did the communist experience affect subsequent economic behavior of the people who had lived under the communist system? The recent literature exploiting German division and reunification covers a wide range of economic measures, including entrepreneurship, job satisfaction, stock-market participation, savings behavior, and inflation expectations. It is hard to draw sweeping conclusions across this range of outcomes, but we will point to some enduring effects of communism that are more robust than others to the caveats we describe in the earlier sections. We start with areas of direct effects of communism and then move to topics focused on developments over the phase after reunification.

\footnotetext{
${ }^{12}$ Arguably, migration unleashed by Soviet occupation or the foundation of the GDR could be defined as part of a more broadly defined communist "treatment".
} 
One question studied is whether the centrally planned economy took away the spirit of entrepreneurship. Self-employment (which typically overlaps with entrepreneurialism) was highly restricted under communism. However, post-reunification differences in entrepreneurship seem to be at least partly the result of persistence from before World War II rather than a pure result of communism. Even when taking the broader view that selective migration before 1961 may be regarded as an effect of communism, Fritsch and Wyrwich (2014) document regional persistence of preferences for entrepreneurship between pre-World War II and today. However, not all entrepreneurial spirit is gone. Fuchs-Schündeln (2009) shows that those who are self-employed in the first ten years after the end of communism display higher job satisfaction compared to their retrospective job satisfaction in 1985.

The GDR offered its citizens very limited opportunities to invest. Stocks were the incarnation of a capitalist system that was despised. Laudenbach et al. (2019) present evidence that East Germans still invest significantly less in the stock market in the 2000s. It seems that the effects are stronger for individuals exposed to stronger communist priming, like those living in communist "showcase cities" or cities of Olympic gold medalists. In contrast, East Germans with negative experiences - those experiencing greater environmental pollution, suppression of religious beliefs, or without access to Western television-invest more in the stock market today. These differences are consistent with lasting effects of communism on stock-market participation. There are also effects on investment types: Consistent with communist friendsand-foes propaganda, East Germans are more likely to hold stocks of companies in (ex-) communist countries such as China, Russia, and Vietnam.

Similarly, there is evidence that communism permanently affected savings behavior. Fuchs-Schündeln and Schündeln (2005) show that after reunification, precautionary wealth as a percentage of all wealth in the East is nearly twice that in the West (22.1 vs. 12.9 percent). Using the surprise effect of reunification for identification, they exploit differences of East Germans with different occupations based on the idea that the choices made under communism were optimal in that context but may suddenly no longer be optimal under the new environment. Specifically, while labor-income risk under communism was essentially zero, some occupations made for safe civil servant careers after reunification whereas others became risky private-sector jobs. German reunification also constitutes a large unanticipated shock to labor and retirement incomes, as well as to wealth levels. Fuchs-Schündeln (2008) shows that East Germans have higher savings rates after reunification, largely to make up for a perceived gap in retirement savings under the new capitalist regime-consistent with a precautionary saving motive. 
Inhabitants of East Germany were used to zero (official) inflation in their centrally planned economy. ${ }^{13}$ Reunification came with a fast increase in prices after the abolishment of price controls. Inflation expectations of East Germans continue to be substantially higher than those of West Germans, even decades after reunification (Goldfayn-Frank and Wohlfart 2020). Arguably, concerns about pre-existing differences in inflation expectations or selective migration on inflation expectations are farfetched in this case. Instead, these results suggest that the experience of communism and the subsequent transition shock have had long-lasting effects on economic expectations.

\section{Political Preferences}

The literature also studies whether life under communism permanently affected political preferences. In their seminal study, Alesina and Fuchs-Schündeln (2007) show that former residents of the German Democratic Republic differ from those of the Federal Republic of German in their thinking about market capitalism and the role of the state in providing social services, insurance, and redistribution from the rich to the poor, using data from the German Socioeconomic Panel (SOEP). ${ }^{14}$ The authors are careful in considering the identification challenges we described earlier. They point out that before World War II, income per capita did not differ substantially between East and West German states and across Prussian provinces at an aggregate level, to the extent that the regions are separable. They also argue that destruction during World War II was major but universal in both parts of Germany. ${ }^{15}$ Addressing innerGerman migration, they argue that self-selection motives are unlikely to be strong enough to explain away their effects. Based on our more fine-grained and extensive evidence on preWorld War II differences in communist vote shares and economic structures as well as selective migration by occupation and education, it is conceivable that some of the effect attributed to the exposure to the communist political system is the result of pre-existing differences and selective migration.

\footnotetext{
${ }^{13}$ Even though state propaganda promoted consumer price stability, residents of East Germany in fact experienced substantial hidden inflation, for example, through changes in product lines. Official price statistics did not include changes from new and enhanced products (Heske 2009, pp. 154ff).

${ }^{14}$ Relatedly, Corneo and Grüner (2002) found that, in 1992, Eastern Europeans had stronger preferences for redistribution than individuals from Western countries.

${ }^{15}$ As discussed above, destruction during World War II was indeed quite similar, but the East was substantially more affected by dismantling and reparations. This might well have affected calls for intervention and redistribution in the early years of East Germany and should arguably be attributed to Soviet occupation as opposed to life under communism in the GDR.
} 
A way to circumvent some of these issues of pre-existing differences is to take 1990 as the starting point and focus on convergence in attitudes after the fall of communism. Alesina and Fuchs-Schündeln (2007) present evidence of convergence in preferences after reunification, which points to some dynamic influence of political systems in the German context. Similarly, Svallfors (2010) documents considerable convergence in attitudes towards state intervention between East and West Germany using International Social Survey Programme (ISSP) data for the years 1990, 1996, and 2006. But in this case, a flow of Westernsocialized people to the East could lead to convergence because of changes in ISSP sample composition over time. Still, the combined evidence leaves little doubt that communism had some enduring effect on political preferences. At the same time, it would be unwise to conclude that German reunification can be treated as a natural experiment for any outcome of interest.

Corroborating evidence is based on differences within East Germany. On some accounts, East Germans living close to the inner-German border tended to have harder lives during the times of German division: authorities implemented forced relocation of whole villages, frequent controls that may have resulted in mental stress, and even more limited freedoms than elsewhere in East Germany. Avdeenko (2018) finds that the successor party to the GDR's communist party captures a lower vote share in the border area than in other parts of East Germany. Concerns about pre-existing differences are directly addressed by drawing on 1919-1933 election results. If anything, communist vote shares were higher in the border area than in other parts of the later GDR, suggesting that the results of a turn away from communism are even stronger once pre-World War II preferences are taken into account. A related methodology uses the number of years under communism as a key variable. The German Socioeconomic Panel includes time-varying information on political attitudes, in conjunction with variation in year of birth and hence time under communism and after communism. Carl (2018) shows that those having spent more time under communism in the East, where exposure to foreigners was limited, are more opposed to immigration. Measuring exposure to communism as a continuous variable reduces some of the concerns about pre-existing differences and selective migration.

It is also revealing to compare West Germans in West Germany to West Germans in East Germany and vice versa. Brosig-Koch et al. (2011) run lab experiments with students in the cities of Magdeburg (East Germany) and Essen (West Germany) in 1995 and 2009. East Germans show consistently less fairness and willingness to cooperate in solidarity games, with no convergence in the 20 years after reunification. West German students studying in the East differ significantly from those studying in the West. In fact, they show similarities with East 
German students. The authors see this as consistent with two potential explanations: West Germans in East Germany either have partly accommodated to the East German behavioral norms or they were more likely to move to the East because they could align themselves better to the social behavior in East Germany-which underlines the importance of considering selective migration.

Overall, papers that exclusively look at the extensive margin of exposure to communism run a risk of over-estimating treatment effects because of pre-World War II differences in communist leanings and selective migration based on preferences for or against communist ideas. However, studies that exploit continuous measures of communist experience (e.g., geographic variation or time under communism) and those exploiting convergence in political preferences after the fall of communism suggest rather long-lasting effects on political preferences.

\section{Culture}

A large literature looks at cross-German outcomes in the area of culture such as trust, fairness, self-reliance, time preferences, conspicuous consumption, and tax morale. In many areas, cultural values continue to differ between East and West.

Trust is considered to be one of the most important cultural drivers of economic exchange (Arrow 1972). Social trust toward other people is lower in East Germany and does not show signs of convergence. Given lower levels of pre-World War II church attendance as a measure of community interaction, it seems likely that some of this reflects long-term persistence, as opposed to an effect of communism. Evidence from different datasets shows that East Germans are significantly less trusting towards other people than West Germans and that these attitudes are not converging - see Rainer and Siedler (2009) for the German General Social Survey and Heineck and Süssmuth (2013) for the German Socioeconomic Panel. Interestingly, however, Rainer and Siedler show that trust in institutions has converged after reunification, suggesting political systems matter in this case. Going beyond trust, Heineck and Süssmuth find that while East Germans are more risk-loving after reunification, there is convergence in risk attitudes between East and West Germans. Looking at differences in perceived fairness and cooperation, they find no evidence of convergence between individuals in the two parts of Germany. To the extent that there is evidence of convergence after reunification in the two studies, concerns about pre-World War II differences and pre-1961 German-German migration are less warranted. 
Lower trust in other people can also be seen in higher investment in strong ties such as close friends compared to weak ties such as club membership or church attendance. Using the German Socioeconomic Panel, Boenisch and Schneider (2013) demonstrate that persons who grew up in East Germany exhibit this specific social capital mix, which also corresponds with lower geographic mobility. Given our evidence of lower church attendance in the East well before World War II, some of this presumed effect of communism likely originates in longerterm historic differences.

It is often argued that with its ubiquitous influence on people's lives, communism led to a lack of self-reliance. Bauernschuster et al. (2012) show that this is indeed the case when conditioning on regional differences in economic development. But in line with what we discussed earlier, they also show that the socialist regime affected the composition of the East German population by inducing selective migration before the construction of the Berlin Wall in 1961.

The planned economy of East Germany disappointed its citizens in many ways. Wait times for cars could be well over a decade. Not surprisingly, East German doctrine taught people to live sparingly and strive for improvement of their performance in the future. Consistent with this doctrine, Friehe and Pannenberg (2020) find that former residents of the GDR are less present-biased. While the authors address selective East-West migration of impatient people by using information about parent's region of origin and retrospective information on East-West migration available in a subsample, pre-World War II differences are a potential source of concern. If time preferences vary by some of the dimensions for which we uncovered pre-existing East-West differences_-say, between blue- and white-collar workerspart of the apparent effect of communism might reflect long-term persistence.

Following the theme of communism-induced limits to consumption choices, some papers exploit the fact that reunification opened up new consumption opportunities. Friehe and Mechtel (2014) show that East Germans display more conspicuous consumption-that is, they spend more on items that display high social status. In a similar vein, Dragone and Ziebarth (2017) show that when a larger variety of food products became readily accessible after the fall of the Wall, East Germans consumed more novel Western food and gained more weight than West Germans. While communism first constrained consumer choice, the transformation period following reunification supported a further differentiation of consumption patterns.

Culture is also reflected in tax morale, that is, the willingness to pay taxes. In fact, tax morale can be seen as a form of solidarity. A stronger preference for redistribution suggested by Alesina and Fuchs-Schündeln (2007) needs the support of honest taxpayers to have the 
desired consequences. In line with this reasoning, Möhlmann (2014) documents a persistently higher tax morale in East Germany and no sign of quick convergence. We are not aware of data on tax morale before World War II. Yet preferences for communism expressed via higher communist vote shares before World War II and selective migration before 1961 suggest the possibility that East Germans might have had higher tax morale to begin with, in which case the effect of living under communism on tax morale might be over-estimated.

Finally, evidence on how life satisfaction responds to circumstances has also been used to measure cultural values. For example, Van Hoorn and Maseland (2010) find that getting divorced hurts East Germans' happiness less than it does for West Germans, implying that East and West Germans respond differently to the same circumstance. Considering a wide range of aspects, East Germans appear to be more likely to entertain cultural values conducive to economic performance, such as a stronger dislike of unemployment. The authors conclude that "the belief that economic differences between Eastern and Western Germany are a result of a communist cultural legacy may be largely a myth.” We would not go as far, as some of the studies discussed above show strong evidence of enduring effects of communism on cultural values. But our reservation is that the magnitude of effects attributed to the communist regime may in some cases be over-estimated.

\section{Gender Roles}

Several papers also examine gender-related aspects of the German experience of separation and reunification, including sex-role attitudes, female labor-force participation, gender-specific educational achievement, and family-formation behavior.

East German institutions encouraged female employment, while the West German system deterred women, in particular mothers, from full-time employment. Using the German General Social Survey, Bauernschuster and Rainer (2012) show that East Germans are significantly more likely to hold egalitarian sex-role attitudes than West Germans, with no sign of convergence after reunification. Campa and Serafinelli (2019) present similar results on sexrole attitudes using the German Socioeconomic Panel and a regression discontinuity design focused on areas around the inter-German border. Furthermore, positive attitudes towards female employment are stronger in areas where growth in female employment was larger. Lippmann et al. (2020) show that East German women contribute a larger share to household income. At the same time, West German women who contribute more to household income also put in more housework hours. 
To what extent might these differences be influenced by pre-separation history of the sort we discussed earlier? Wyrwich (2017) presents detailed analyses of female labor-force participation in 1925 and after World War II and addresses the concern we raised by using difference-in-differences estimation. However, Beblo and Görges (2018) find no substantial gender differences in preferences for work between what would later become East and West in pre-World War II data. The key difference here seems to be that they look at female labor-force participation as a share of the total, whereas it seems more natural to look at female labor-force participation rates, which do differ between East and West as we show above following Wyrwich (2019). To the extent that there is substantial persistence in female labor-force participation, at least some of the effect attributed to communism by the literature on gender norms in the labor market may pick up persistence.

Going beyond the labor market, Lippmann and Senik (2018) show that the stereotypical underperformance of girls in math is sharply lower in the regions of former East Germany, in contrast with those of former West Germany. The difference is not explained by differences in economic conditions or teaching styles across the former political border. A potential concern about pre-existing differences relates to long-lasting Protestant-Catholic differences across Germany and the smaller gender gap in Protestant areas (Becker and Woessmann 2008).

In another study of socialist education, Fuchs-Schündeln and Masella (2016) start from the observation that access to college was restricted under communism. With reunification, high-school graduates had more choice over their post-secondary education. To estimate the effect of socialist schooling on tertiary education, they exploit sharp birth-date cutoffs for school entrance that led to variation in the length of exposure to the East German education system. The authors show that an additional year of socialist schooling decreased the probability of obtaining a college degree for both genders and negatively affected several indicators of the labor-market prospects for men. This methodology is unaffected by the arguments we raised. The results suggest that growing up under socialist education had real effects on labor-market careers, especially for men.

Finally, nonmarital births are the norm in Eastern Germany (58.1 percent of all births in 2009), whereas they are the exception (26.5 percent) in Western Germany (Klüsener and Goldstein 2016). As discussed earlier, differences in nonmarital births predate the 1945 division of Germany, showing that at least some of the East-West difference is likely the result of longrun persistence in attitudes toward gender.

Overall, while the impact of the socialist regime on gender roles seems beyond doubt, numerically some of the results in the literature are likely over-estimated because of the pre- 
existing differences in female labor-force participation and the stronger historical drive for gender equality in the largely Protestant East.

\section{Conclusion}

The separation into the communist German Democratic Republic and the capitalist Federal Republic of Germany in 1949 and their reunification in 1990 both happened rapidly and largely unexpectedly. This does not necessarily mean, however, that these events constitute a natural experiment that randomly assigned similar populations to two different political regimes. We show that, in fact, the East and West German populations differed already before World War II. For instance, people in what would later become the communist East were more likely to be working class, less likely to be self-employed, more likely to vote for the communist party, less likely to attend church, and more likely to experience female labor-force participation. To the extent that such differences persist over time, they likely introduce an upward bias in estimated effects of communist exposure on outcomes such as lack of entrepreneurship, left-leaning political preferences, lack of community participation, and equal gender roles.

The East was also more heavily affected by war-related damages, dismantling, and reparation costs to the occupying forces in the immediate aftermath of World War II. Furthermore, roughly one in five people living in the East in 1945 migrated to the West before the construction of the Berlin Wall in 1961. As this out-migration was highly selective, this creates an additional source for potentially persisting East-West differences. Thus, any EastWest differences in reunified Germany cannot necessarily be interpreted as a pure effect of communism. Furthermore, evidence of pre-World War II differences persisting over many decades suggests that convergence between the two parts of Germany may take longer than commonly thought.

With this background in mind, is there an effect of communism in the German case? The answer is certainly yes_-but each research question requires individual consideration of the aforementioned challenges. More robust evidence for the impact of political systems comes from the convergence of some economic behaviors and political (more than social) attitudes between the two parts of Germany after reunification. Living under the East German regime also seems to have affected consumption patterns persistently. Trust in the state may have been affected by German separation but has converged between East and West after reunification. Gender roles may have been affected along several dimensions, but female labor-force 
participation and fertility behavior also appear to have a strong component of persistence dating back far before World War II.

The broader lesson is that researchers should not be too quick to take the formation of political systems as exogenous. Given that political preferences are endogenous, for instance, to previous experiences (Fuchs-Schündeln and Schündeln 2015), political systems may become endogenous too. This is obvious in the case of revolutions initiated by populations unhappy with their current political system. But even when outside powers initiate a regime transition and when borders are redrawn, any "effect" of the new regime should be carefully assessed with regards to pre-existing conditions and selective migration, as those unsatisfied with the regime change might migrate out, leaving behind those who are more disposed to go along with the new system. 


\section{References}

Akerlof, George A., Andrew K. Rose, Janet L. Yellen, Helga Hessenius (1991). East Germany in from the cold: The economic aftermath of currency union. Brookings Papers on Economic Activity (1): 1-105.

Alesina, Alberto, Nicola Fuchs-Schündeln (2007). Goodbye Lenin (or not?): The effect of communism on people. American Economic Review 97 (4): 1507-1528.

Angrist, Josh (2002). How do sex ratios affect marriage and labor markets? Evidence from America's second generation. Quarterly Journal of Economics 117 (3): 997-1038.

Arrow, Kenneth J. (1972). Gifts and exchanges. Philosophy \& Public Affairs 1 (4): 343-362.

Avdeenko, Alexandra (2018). Long-term evidence of retrospective voting: A natural experiment from the German Democratic Republic. European Economic Review 103: 83-107.

Baar, Lothar, Rainer Karlsch, Werner Matschke (1995). Kriegsschäden, Demontagen und Reparationen. In Materialien der Enquete-Kommission „Aufarbeitung von Geschichte und Folgen der SED-Diktatur “, Band II/2. Frankfurt/Main: Nomos: 868-988.

Bauernschuster, Stefan, Oliver Falck, Robert Gold, Stephan Heblich (2012). The shadows of the socialist past: Lack of self-reliance hinders entrepreneurship. European Journal of Political Economy 28 (4): 485-497.

Bauernschuster, Stefan, Helmut Rainer (2012). Political regimes and the family: how sex-role attitudes continue to differ in reunified Germany. Journal of Population Economics 25 (1): 527.

Beblo, Miriam, Luise Görges (2018). On the nature of nurture. The malleability of gender differences in work preferences. Journal of Economic Behavior \& Organization 151: 19-41.

Becker, Sascha O., Markus Nagler, Ludger Woessmann (2017). Education and religious participation: City-level evidence from Germany's secularization period 1890-1930. Journal of Economic Growth 22 (3): 273-311.

Becker, Sascha O., Ludger Woessmann (2008). Luther and the girls: Religious denomination and the female education gap in nineteenth-century Prussia. Scandinavian Journal of Economics 110 (4): 777-805.

Becker, Sascha O., Ludger Woessmann (2009). Was Weber wrong? A human capital theory of Protestant economic history. Quarterly Journal of Economics 124 (2): 531-596.

Becker, Sascha O., Ludger Woessmann (2013). Not the opium of the people: Income and secularization in a panel of Prussian counties. American Economic Review, Papers and Proceedings 103 (3): 539-544.

Becker, Sascha O., Ludger Woessmann (2018). Social cohesion, religious beliefs, and the effect of Protestantism on suicide. Review of Economics and Statistics 100 (3): 377-391.

Boenisch, Peter, Lutz Schneider (2013). The social capital legacy of communism-results from the Berlin Wall experiment. European Journal of Political Economy 32: 391-411.

Borjas, George J. (1987). Self-selection and the earnings of immigrants. American Economic Review 77 (4): 531-553.

Brosig-Koch, Jeannette, Christoph Helbach, Axel Ockenfels, Joachim Weimann (2011). Still different after all these years: Solidarity behavior in East and West Germany. Journal of Public Economics 95 (11): 1373-1376. 
Campa, Pamela, Michel Serafinelli (2019). Politico-economic regimes and attitudes: Female workers under state socialism. Review of Economics and Statistics 101 (2): 233-248.

Carl, Matthew (2018). The effect of Communism on people's attitudes toward immigration. SSRN Discussion Paper 3246617.

Corneo, Giacomo, Hans Peter Grüner (2002). Individual preferences for political redistribution. Journal of Public Economics 83 (1): 83-107.

Dragone, Davide, Nicolas R. Ziebarth (2017). Non-separable time preferences, novelty consumption and body weight: Theory and evidence from the East German transition to capitalism. Journal of Health Economics 51: 41-65.

Eder, Christoph, Martin Halla (2018). On the Origin and Composition of the German East-West Population Gap. IZA Discussion Paper 12031. Bonn: Institute of Labor Economics.

Fairlie, Robert W., Magnus Lofstrom (2015). Immigration and entrepreneurship. In Handbook of the Economics of International Migration, Vol. 1, edited by Barry R. Chiswick, Paul W. Miller. Amsterdam: North Holland: 877-911.

Falter, Jürgen W. (2014). Political cleavages in the Weimar republic and the rise of National Socialism. European Political Science 13 (1): 106-116.

Falter, Jürgen W., Dirk Hänisch (1990). Election and Social Data of the Districts and Municipalities of the German Empire from 1920 to 1933. ZA8013 Data file Version 1.0.0, doi:10.4232/1.8013. Cologne: GESIS Data Archive.

Foreign Relations of the United States (1968). Diplomatic Papers 1945, Volume III, European Advisory Commission; Austria; Germany. Document (44)2. Washington, D.C.: U.S. Government Printing Office.

Friehe, Tim, Mario Mechtel (2014). Conspicuous consumption and political regimes: Evidence from East and West Germany. European Economic Review 67: 62-81.

Friehe, Tim, Markus Pannenberg (2020). Time preferences and political regimes: Evidence from reunified Germany. Journal of Population Economics 33 (1): 349-387.

Fritsch, Michael, Michael Wyrwich (2014). The long persistence of regional levels of entrepreneurship: Germany, 1925-2005. Regional Studies 48 (6): 955-973.

Fuchs-Schündeln, Nicola (2008). The response of household saving to the large shock of German reunification. American Economic Review 98 (5): 1798-1828.

Fuchs-Schündeln, Nicola (2009). On preferences for being self-employed. Journal of Economic Behavior \& Organization 71 (2): 162-171.

Fuchs-Schündeln, Nicola, Paolo Masella (2016). Long-lasting effects of socialist education. Review of Economics and Statistics 98 (3): 428-441.

Fuchs-Schündeln, Nicola, Matthias Schündeln (2005). Precautionary savings and selfselection: Evidence from the German reunification "experiment". Quarterly Journal of Economics 120 (3): 1085-1120.

Fuchs-Schündeln, Nicola, Matthias Schündeln (2015). On the endogeneity of political preferences: Evidence from individual experience with democracy. Science 347 (6226): 11451148.

Goldfayn-Frank, Olga, Johannes Wohlfart (2020). Expectation formation in a new environment: Evidence from the German reunification. Journal of Monetary Economics: forthcoming. 
Grashoff, Udo (2019). Driven into suicide by the East German regime? Reflections on the persistence of a misleading perception. Central European History 52 (2): 310-332.

Grogger, Jeffrey, Gordon H. Hanson (2011). Income maximization and the selection and sorting of international migrants. Journal of Development Economics 95 (1): 42-57.

Hänisch, Dirk (1989). Inhalt und Struktur der Datenbank »Wahl- und Sozialdaten der Kreise und Gemeinden des Deutschen Reiches von 1920 bis 1933«. Historical Social Research 14 (1): 39-67.

Heidemeyer, Helge (1994). Flucht und Zuwanderung aus der SBZ/DDR 1945/1949-1961: Die Flüchtlingspolitik der Bundesrepublik Deutschland bis zum Bau der Berliner Mauer. Düsseldorf: Droste.

Heineck, Guido, Bernd Süssmuth (2013). A different look at Lenin’s legacy: Social capital and risk taking in the Two Germanies. Journal of Comparative Economics 41 (3): 789-803.

Heske, Gerhard (2009). Volkswirtschaftliche Gesamtrechnung DDR 1950-1989: Daten, Methoden, Vergleiche. Historical Social Research, Supplement 21: 1-359.

Hölscher, Lucian (2001). Datenatlas zur religiösen Geographie im protestantischen Deutschland: Von der Mitte des 19. Jahrhunderts bis zum Zweiten Weltkrieg. 4 vols. Berlin: Walter de Gruyter.

Jessen, Ralph (1999). Akademische Elite und kommunistische Diktatur: Die ostdeutsche Hochschullehrerschaft in der Ulbricht-Ära. Wittingen: Vandenhoeck und Ruprecht.

Klüsener, Sebastian, Joshua R. Goldstein (2016). A long-standing demographic East-West divide in Germany. Population, Space and Place 22 (1): 5-22.

Kowalski, Hans-Günter (1971). Die "European Advisory Commission" als Instrument alliierter Deutschlandplanung 1943-1945. Vierteljahrshefte für Zeitgeschichte 19 (3): 261-293.

Laudenbach, Christine, Ulrike Malmendier, Alexandra Niessen-Ruenzi (2019). The longlasting effects of experiencing communism on attitudes towrads financial markets. Working Paper.

Lippmann, Quentin, Alexandre Georgieff, Claudia Senik (2020). Undoing gender with institutions: Lessons from the German division and reunification. Economic Journal: forthcoming.

Lippmann, Quentin, Claudia Senik (2018). Math, girls and socialism. Journal of Comparative Economics 46 (3): 874-888.

Luy, Marc (2020). Lebenserwartung in Deutschland. Data available via http://lebenserwartung.info. Data retrieved on February 16, 2020.

Möhlmann, Axel (2014). Persistence or convergence? The East-West tax-morale gap in Germany. FinanzArchiv 70 (1): 3-30.

Parey, Matthias, Jens Ruhose, Fabian Waldinger, Nicolai Netz (2017). The selection of highskilled emigrants. Review of Economics and Statistics 99 (5): 776-792.

Rainer, Helmut, Thomas Siedler (2009). Does democracy foster trust? Journal of Comparative Economics 37 (2): 251-269.

Rosés, Joan Ramón, Nikolaus Wolf, eds. (2018). The economic development of Europe's regions: A quantitative history since 1900. Routledge. 
Siebert, Horst (1991). German unification: The economics of transition. Economic Policy 6 (13): 287-340.

Simpser, Alberto, Dan Slater, Jason Wittenberg (2018). Dead but not gone: Contemporary legacies of communism, imperialism, and authoritarianism. Annual Review of Political Science 21 (1): 419-439.

Sleifer, Jaap (2006). Planning Ahead and Falling Behind: The East German Economy in Comparison with West Germany 1936-2002. Jahrbuch für Wirtschaftsgeschichte, Beiheft 8. Berlin: Akademie Verlag.

Steiner, André (2013). The Plans that Failed: An Economic History of the GDR. New York: Berghahn Books.

Svallfors, Stefan (2010). Policy feedback, generational replacement, and attitudes to state intervention: Eastern and Western Germany, 1990-2006. European Political Science Review 2 (1): 119-135

van Ark, Bart (1996). Convergence and divergence in the European periphery: Productivity in Eastern and Southern Europe in retrospect. In Quantitative Aspects of Post-War European Economic Growth, edited by Bart van Ark, Nicholas Crafts. Cambridge: Cambridge University Press: 271-326.

van Hoorn, André, Robbert Maseland (2010). Cultural differences between East and West Germany after 1991: Communist values versus economic performance? Journal of Economic Behavior \& Organization 76 (3): 791-804.

van Melis, Damian (2006). „Republikflucht“: Flucht und Abwanderung aus der SBZ/DDR 1945 bis 1961. München: Oldenbourg.

Wagner, Andrea (2008). Die Entwicklung des Lebensstandards in Deutschland zwischen 1920 und 1960. Jahrbuch für Wirtschaftsgeschichte, Beiheft 12. Akademie Verlag.

Wolf, Nikolaus (2009). Was Germany ever united? Evidence from intra- and international trade, 1885-1933. Journal of Economic History 69 (3): 846-881.

Wyrwich, Michael (2017). Women and the labour market in East and West Germany: Socialist legacy and pre-socialist tradition. Jena Economic Research Paper 2017-015. Jena: Friedrich Schiller University of Jena.

Wyrwich, Michael (2019). Historical and current spatial differences in female labour force participation: Evidence from Germany. Papers in Regional Science 98 (1): 211-239. 
Figure 1: GDP per Capita and Life Expectancy in East and West Germany, 1925-2010

\section{GDP per capita}

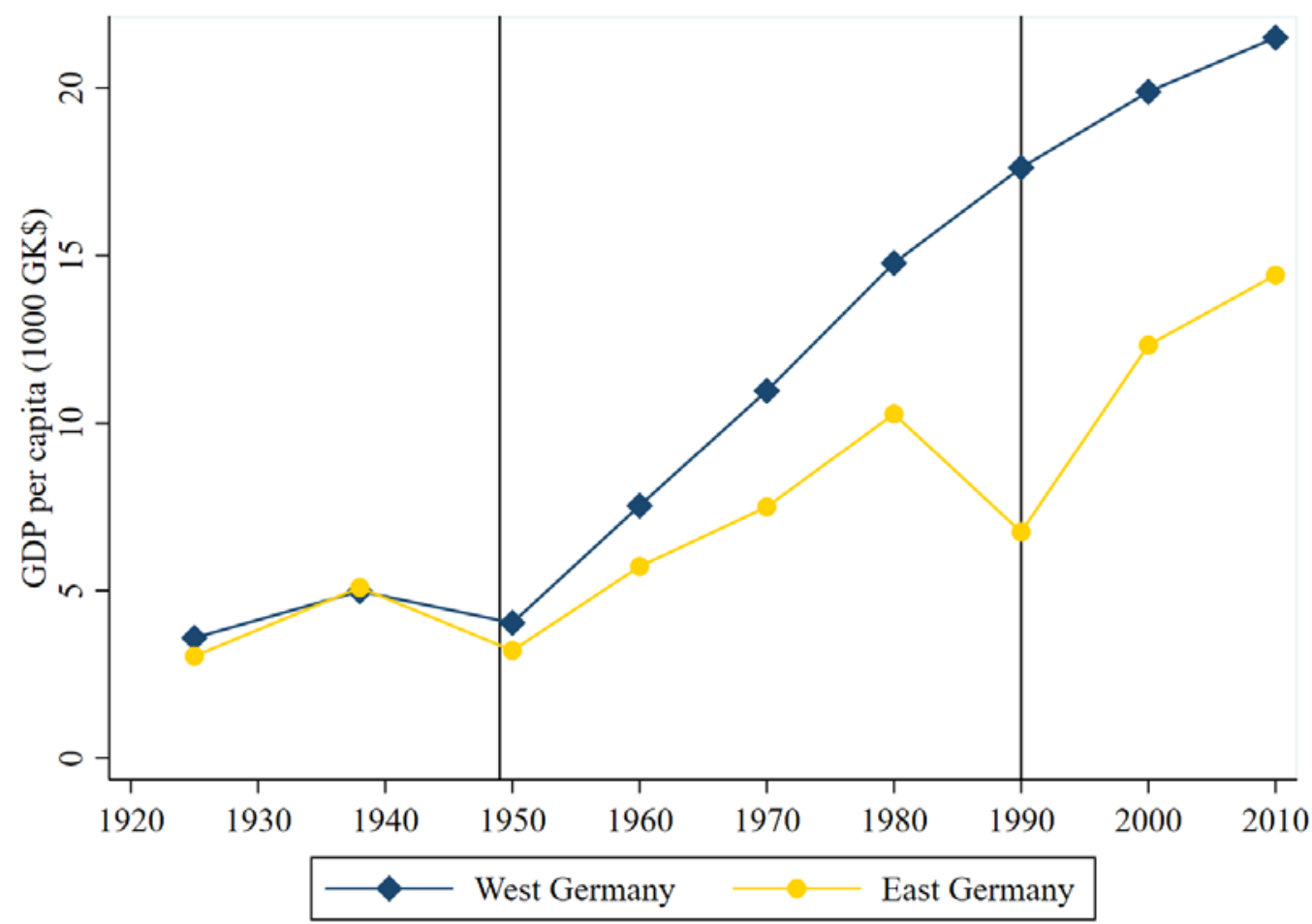

\section{Life expectancy}

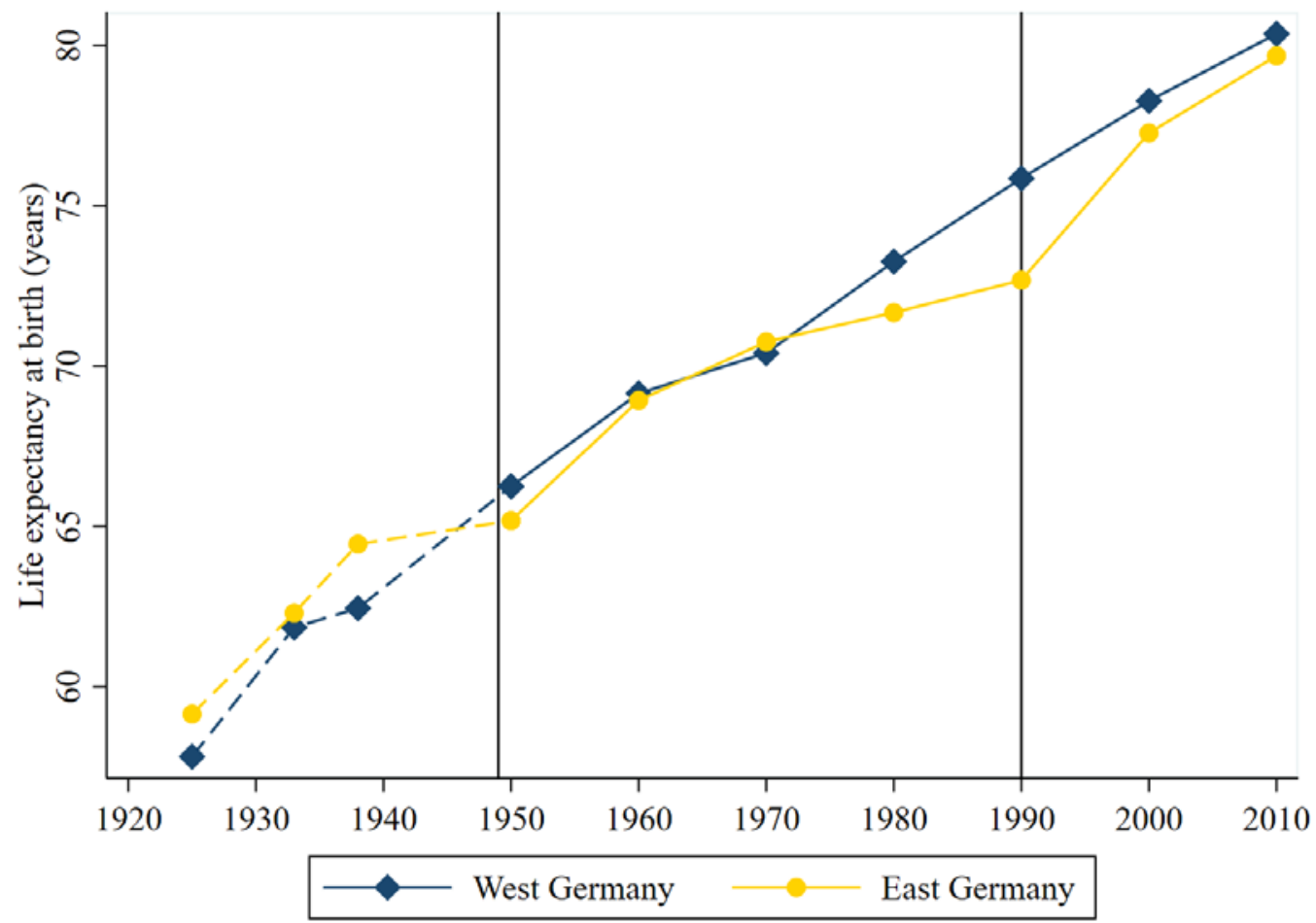

Notes: GDP data are in 1990 Geary-Khamis dollars and exclude Berlin. Source: Rosés and Wolf (2018), own calculations. Pre-1950 life expectancy data comprise the states of Baden, Bavaria, Hesse, and Wurttemberg (equiweighted average) for West Germany and Thuringia and Saxony for East Germany. Source: Wagner (2008), own calculations. From 1950 onwards, life expectancy data comprise the respective entire territories. Source: Luy (2020). Vertical lines represent German separation (1949) and reunification (1990). 
Figure 2: German Post-World War II Occupation Zones, Pre-World War II Provinces, and End-of-War Frontline

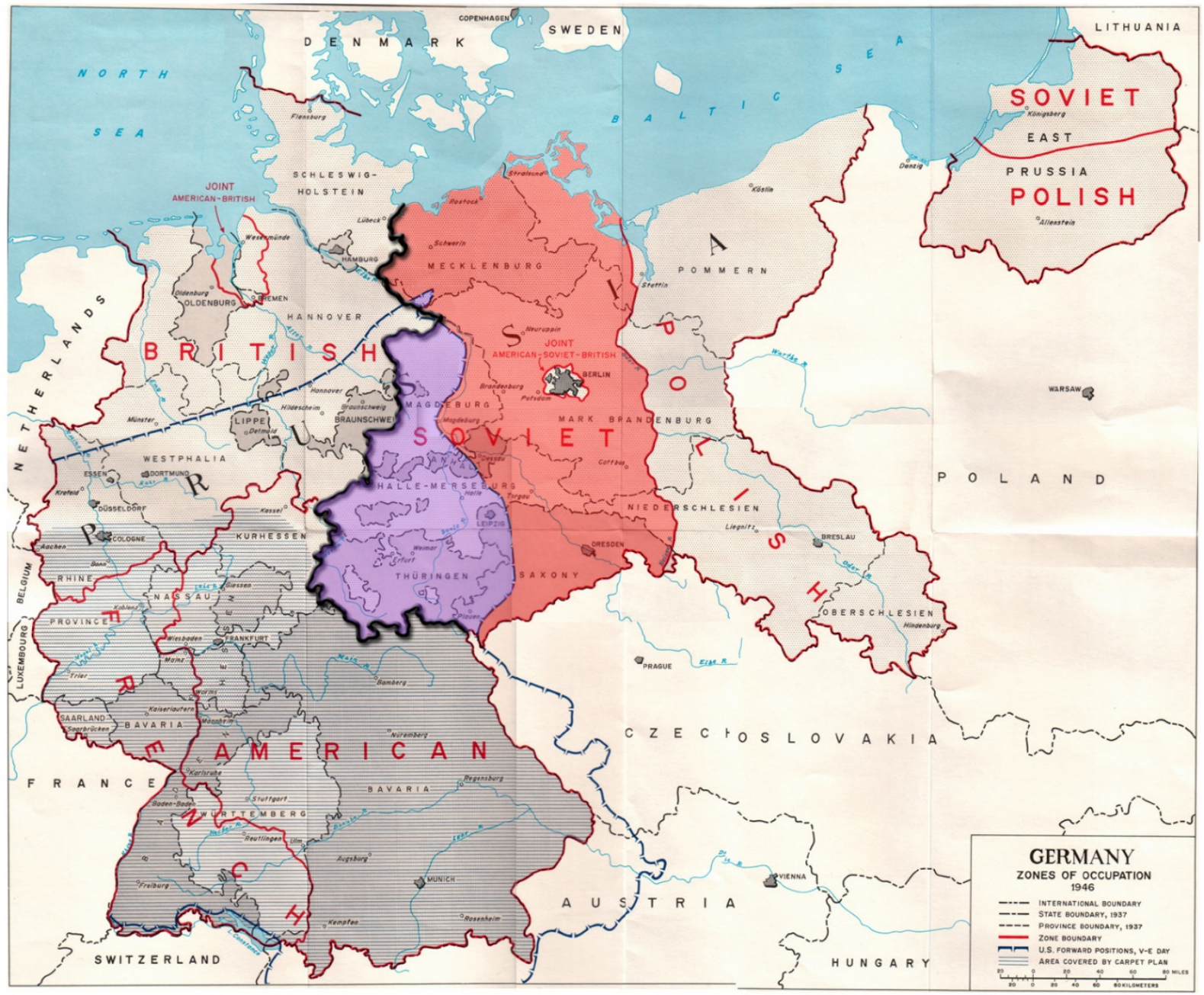

Notes: Occupation zones in post-war Germany, highlighting the Soviet zone (red and purple), the inner German border (heavy black line), and the zone from which American forces withdrew in July 1945 (purple). With minimal exceptions, the ultimate border between the German Democratic Republic and the Federal Republic of Germany in the years 1949-1990 follows the pre-World War II province borders, the border proposed in the EAC protocols in 1944 and 1945, as well as the Western border of the Soviet occupation zone from 1945-1949 (depicted). Source: Earl F. Ziemke, The U.S. Army in the Occupation of Germany, 1975. Library of Congress, Catalog Card Number 75-619027. 
Figure 3: The Working-class Share in 1925: Spotting the GDR Before It Existed

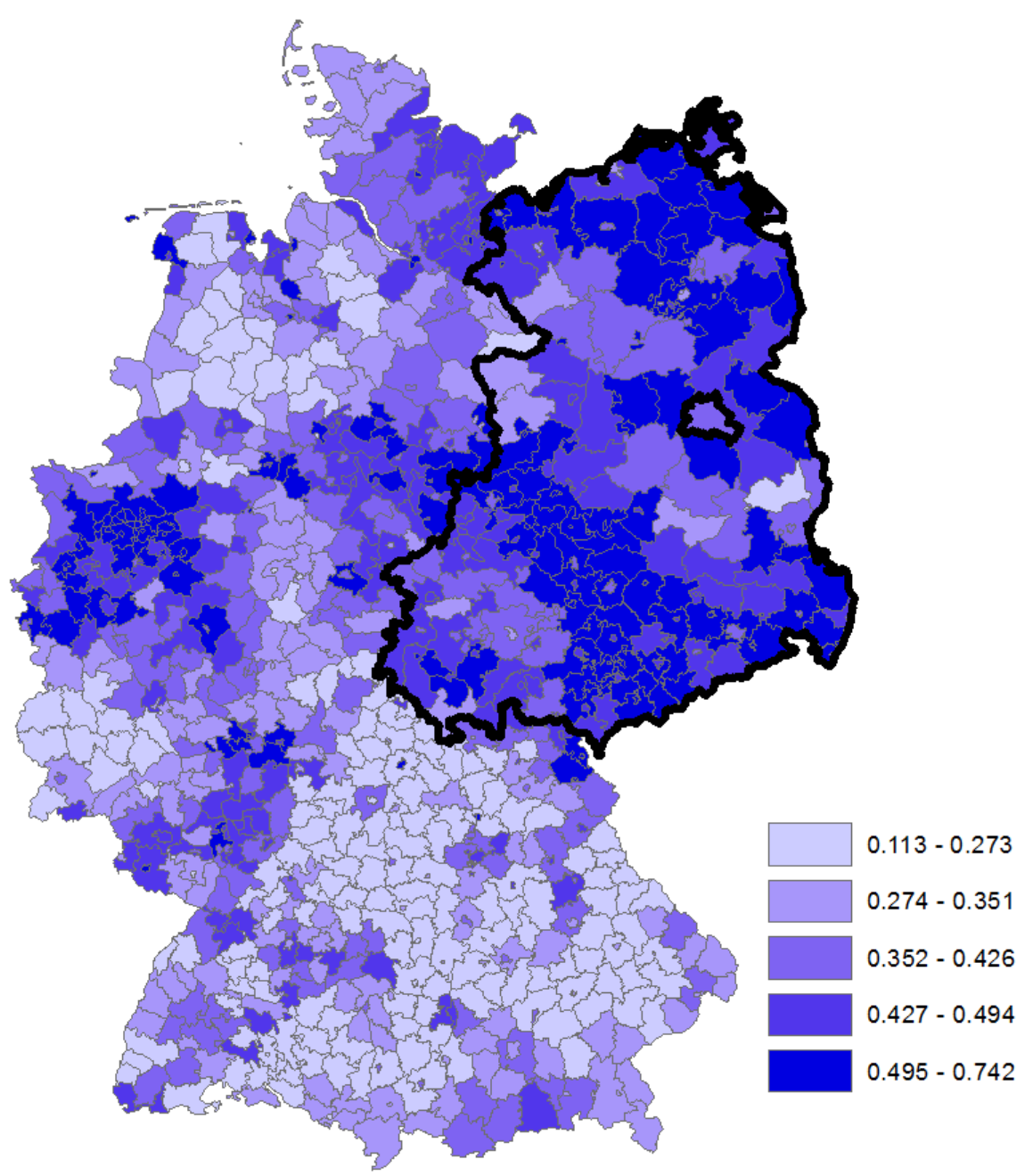

Notes: Colors refer to quintiles. Missing data imputed by nearest neighbor. Source: Own depiction based on county-level census data in Falter and Hänisch (1990). 


\begin{tabular}{|c|c|c|c|c|}
\hline & \multirow{2}{*}{$\begin{array}{l}\text { Full German } \\
\text { sample }\end{array}$} & \multicolumn{3}{|c|}{ Band around the East-West border } \\
\hline & & $<=200 \mathrm{~km}$ & $<=100 \mathrm{~km}$ & Border counties \\
\hline \multicolumn{5}{|l|}{ Economic outcomes } \\
\hline \multicolumn{5}{|l|}{ Working-class share (1925) } \\
\hline Constant (West) & $\begin{array}{l}0.356^{* * *} \\
(0.005)\end{array}$ & $\begin{array}{l}0.340^{* * *} \\
(0.006)\end{array}$ & $\begin{array}{l}0.363^{* * *} \\
(0.009)\end{array}$ & $\begin{array}{c}0.369^{* * *} \\
(0.020)\end{array}$ \\
\hline GDR & $\begin{array}{l}0.118^{* * *} \\
(0.007)\end{array}$ & $\begin{array}{l}0.136^{* * *} \\
(0.009)\end{array}$ & $\begin{array}{l}0.108^{* * *} \\
(0.012)\end{array}$ & $\begin{array}{l}0.073^{* * *} \\
(0.024)\end{array}$ \\
\hline \multicolumn{5}{|c|}{ Manufacturing employment share (1925) } \\
\hline Constant (West) & $\begin{array}{l}0.357^{* * *} \\
(0.006)\end{array}$ & $\begin{array}{l}0.332^{* * *} \\
(0.008)\end{array}$ & $\begin{array}{l}0.349^{* * *} \\
(0.012)\end{array}$ & $\begin{array}{l}0.341^{* * *} \\
(0.028)\end{array}$ \\
\hline GDR & $\begin{array}{l}0.083^{* * *} \\
(0.012)\end{array}$ & $\begin{array}{l}0.121^{* * *} \\
(0.015)\end{array}$ & $\begin{array}{l}0.110^{* * *} \\
(0.019)\end{array}$ & $\begin{array}{c}0.031 \\
(0.039)\end{array}$ \\
\hline \multicolumn{5}{|c|}{ Self-employment share (1925) } \\
\hline Constant (West) & $\begin{array}{l}0.273^{* * *} \\
(0.004)\end{array}$ & $\begin{array}{l}0.281^{* * *} \\
(0.005)\end{array}$ & $\begin{array}{l}0.263^{* * *} \\
(0.007)\end{array}$ & $\begin{array}{c}0.269^{* * *} \\
(0.014)\end{array}$ \\
\hline GDR & $\begin{array}{c}-0.084^{* * *} \\
(0.005)\end{array}$ & $\begin{array}{c}-0.093^{* * *} \\
(0.006)\end{array}$ & $\begin{array}{c}-0.068^{* * *} \\
(0.008)\end{array}$ & $\begin{array}{c}-0.039^{* *} \\
(0.017)\end{array}$ \\
\hline \multicolumn{5}{|c|}{ Political preferences } \\
\hline \multicolumn{5}{|c|}{ Communist (KPD) vote share (1924) } \\
\hline Constant (West) & $\begin{array}{l}0.050^{* * *} \\
(0.002)\end{array}$ & $\begin{array}{l}0.037^{* * *} \\
(0.002)\end{array}$ & $\begin{array}{l}0.036^{* * *} \\
(0.003)\end{array}$ & $\begin{array}{l}0.035^{* * *} \\
(0.004)\end{array}$ \\
\hline GDR & $\begin{array}{l}0.049^{* * *} \\
(0.005)\end{array}$ & $\begin{array}{c}0.069^{* * *} \\
(0.006)\end{array}$ & $\begin{array}{l}0.068^{* * *} \\
(0.008)\end{array}$ & $\begin{array}{l}0.021^{*} \\
(0.011)\end{array}$ \\
\hline \multicolumn{5}{|c|}{ Left (SPD+USPD+KPD) vote share (1924) } \\
\hline Constant (West) & $\begin{array}{l}0.254^{* * *} \\
(0.005)\end{array}$ & $\begin{array}{l}0.274^{* * *} \\
(0.008)\end{array}$ & $\begin{array}{l}0.307^{* * *} \\
(0.011)\end{array}$ & $\begin{array}{l}0.316^{* * *} \\
(0.027)\end{array}$ \\
\hline GDR & $\begin{array}{l}0.152^{* * *} \\
(0.008)\end{array}$ & $\begin{array}{l}0.138^{* * *} \\
(0.011)\end{array}$ & $\begin{array}{l}0.100^{* * *} \\
(0.016)\end{array}$ & $\begin{array}{c}0.028 \\
(0.037)\end{array}$ \\
\hline \multicolumn{5}{|l|}{ Culture } \\
\hline \multicolumn{5}{|l|}{ Protestant share (1925) } \\
\hline Constant (West) & $\begin{array}{l}0.490^{* * *} \\
(0.015)\end{array}$ & $\begin{array}{l}0.602^{* * *} \\
(0.021)\end{array}$ & $\begin{array}{c}0.663^{* * *} \\
(0.028)\end{array}$ & $\begin{array}{l}0.754^{* * *} \\
(0.051)\end{array}$ \\
\hline GDR & $\begin{array}{c}0.420^{* * *} \\
(0.016)\end{array}$ & $\begin{array}{c}0.307^{* * *} \\
(0.023)\end{array}$ & $\begin{array}{c}0.240^{* * *} \\
(0.031)\end{array}$ & $\begin{array}{c}0.099 \\
(0.068)\end{array}$ \\
\hline \multicolumn{5}{|c|}{ Church attendance (1900-1910) } \\
\hline Constant (West) & $\begin{array}{c}0.554^{* * *} \\
(0.016)\end{array}$ & $\begin{array}{l}0.651^{* * *} \\
(0.021)\end{array}$ & $\begin{array}{c}0.623^{* * *} \\
(0.032)\end{array}$ & $\begin{array}{l}0.641^{* * *} \\
(0.066)\end{array}$ \\
\hline GDR & $\begin{array}{c}-0.163^{* * *} \\
(0.019)\end{array}$ & $\begin{array}{c}-0.266^{* * *} \\
(0.024)\end{array}$ & $\begin{array}{c}-0.228^{* * *} \\
(0.036)\end{array}$ & $\begin{array}{c}-0.184^{* *} \\
(0.076)\end{array}$ \\
\hline \multicolumn{5}{|c|}{ Gender Roles } \\
\hline \multicolumn{5}{|c|}{ Female labor-force participation (1925) } \\
\hline Constant (West) & $\begin{array}{l}0.325^{* * *} \\
(0.003)\end{array}$ & $\begin{array}{l}0.324^{* * *} \\
(0.004)\end{array}$ & $\begin{array}{l}0.326^{* * *} \\
(0.007)\end{array}$ & $\begin{array}{l}0.308^{* * *} \\
(0.011)\end{array}$ \\
\hline GDR & $\begin{array}{c}0.060^{* * *} \\
(0.006)\end{array}$ & $\begin{array}{c}0.058^{* * *} \\
(0.007)\end{array}$ & $\begin{array}{c}0.049^{* * *} \\
(0.010)\end{array}$ & $\begin{array}{l}0.037^{* *} \\
(0.016)\end{array}$ \\
\hline \multicolumn{5}{|c|}{ Extramarital birth ratio (1937) } \\
\hline Constant (West) & $\begin{array}{c}0.067^{* * *} \\
(0.002)\end{array}$ & $\begin{array}{c}0.070^{* * *} \\
(0.002)\end{array}$ & $\begin{array}{c}0.069^{* * *} \\
(0.002)\end{array}$ & $\begin{array}{c}0.065^{* * *} \\
(0.005)\end{array}$ \\
\hline GDR & $\begin{array}{c}0.033^{* * *} \\
(0.002)\end{array}$ & $\begin{array}{c}0.030^{* * *} \\
(0.003)\end{array}$ & $\begin{array}{c}0.025^{* * *} \\
(0.004)\end{array}$ & $\begin{array}{c}0.014^{*} \\
(0.008) \\
\end{array}$ \\
\hline Observations (vote shares) & 854 & 468 & 244 & 59 \\
\hline
\end{tabular}

Notes: Each pair of “GDR” and “Constant (West)” estimates reflect the result of a separate regression. Countylevel analyses. Distance to border based on county centroids. Robust standard errors in parentheses: significance at ${ }^{*} 10,{ }^{* *} 5,{ }^{* * *} 1$ percent. Data sources: economic outcomes, political preferences, and Protestant share: Falter and Hänisch (1990); Protestant church attendance: Hölscher (2001); female labor-force participation: Wyrwich (2019); extramarital birth ratio: Klüsener and Goldstein (2016). For additional details, see Appendix Table A1. 
Table 2: Comparison of East-West Movers and Local West Germans in 1939: Retrospective Evidence

\begin{tabular}{lcc}
\hline \hline & East-West movers & Local West Germans \\
\hline Occupation in 1939 & & 0.301 \\
Unskilled worker & 0.154 & 0.053 \\
Farmer (self-employed) & 0.057 & 0.113 \\
Family worker & 0.094 & 0.196 \\
Skilled worker & 0.155 & 0.203 \\
White-collar worker & 0.304 & 0.061 \\
Civil servant & 0.135 & 0.072 \\
Self-employed & 0.101 & 0.608 \\
Education & & 0.348 \\
Basic school (Volksschule) & 0.392 & 0.014 \\
Secondary and professional school & 0.490 & 0.012 \\
High school & 0.042 & 0.019 \\
Technical school & 0.027 & 104,128 \\
University & 0.049 & 2,288 \\
\hline Observations & & \\
\hline \hline
\end{tabular}

Notes: Retrospective evidence from German Microcensus 1971. Shares in sample population. Individuals still in education or outside the labor force in 1939 as well as expellees from formerly German territories excluded. 
Table 3: Evidence on East-West Differences

\begin{tabular}{|c|c|c|c|c|}
\hline Paper, Outcome & Data & \multicolumn{2}{|c|}{ Empirical Approach } & Result \\
\hline \multicolumn{5}{|c|}{ Economic outcomes } \\
\hline $\begin{array}{l}\text { Fuchs-Schündeln } \\
\text { and Schündeln } \\
\text { (2005): Saving }\end{array}$ & $\begin{array}{l}\text { SOEP 1992- } \\
2000\end{array}$ & \multicolumn{2}{|c|}{$\begin{array}{l}\text { East-West comparison: } \\
\text { GDR vs. FRG resident; } \\
\text { civil servants vs. other } \\
\text { occupations }\end{array}$} & $\begin{array}{l}\text { Precautionary wealth as share of total wealth in } \\
\text { East amounts to twice that in West after } \\
\text { reunification }\end{array}$ \\
\hline $\begin{array}{l}\text { Fuchs-Schündeln } \\
\text { (2008): Saving }\end{array}$ & $\begin{array}{l}\text { SOEP 1992- } \\
2000\end{array}$ & \multicolumn{2}{|c|}{$\begin{array}{l}\text { East-West comparison: } \\
\text { GDR vs. FRG resident } \\
\text { before } 1990\end{array}$} & $\begin{array}{l}\text { East Germans have higher saving rates than West } \\
\text { Germans; East-West gap increasing in age at } \\
\text { reunification; per cohort, gap declining over time }\end{array}$ \\
\hline $\begin{array}{l}\text { Fuchs-Schündeln } \\
\text { (2009): Job } \\
\text { satisfaction }\end{array}$ & $\begin{array}{l}\text { SOEP 1990- } \\
2000\end{array}$ & \multicolumn{2}{|c|}{$\begin{array}{l}\text { Sample of East } \\
\text { Germans: self- } \\
\text { employed vs. non-self- } \\
\text { employed }\end{array}$} & $\begin{array}{l}\text { Self-employment, mostly prohibited in GDR, } \\
\text { possible after reunification; self-employed in East } \\
\text { report higher job satisfaction than the employed, } \\
\text { even controlling for income and hours worked }\end{array}$ \\
\hline $\begin{array}{l}\text { Fritsch and } \\
\text { Wyrwich (2014): } \\
\text { Entrepreneurship }\end{array}$ & $\begin{array}{l}\text { Regional } \\
\text { data } 1925, \\
1984-2005\end{array}$ & \multicolumn{2}{|c|}{$\begin{array}{l}\text { East-West comparison } \\
\text { over nearly } 100 \text { years }\end{array}$} & $\begin{array}{l}\text { Entrepreneurship rates highly persistent from pre- } \\
\text { WW II to today; West Germany had higher } \\
\text { entrepreneurship already before WW II }\end{array}$ \\
\hline $\begin{array}{l}\text { Laudenbach et al. } \\
\text { (2019): Stock- } \\
\text { market } \\
\text { participation }\end{array}$ & $\begin{array}{l}\text { Retail inves- } \\
\text { tor accounts } \\
\text { of a broker, } \\
2004-2012\end{array}$ & \multicolumn{2}{|c|}{$\begin{array}{l}\text { East-West comparison } \\
\text { and treatment intensity } \\
\text { (“communist cities”) }\end{array}$} & $\begin{array}{l}\text { East Germans invest less in stock market, more } \\
\text { likely to hold stocks of companies in communist } \\
\text { countries (China, Russia, Vietnam); effects } \\
\text { stronger when exposed to communist priming }\end{array}$ \\
\hline $\begin{array}{l}\text { Goldfayn-Frank } \\
\text { and Wohlfart } \\
\text { (2020): Inflation } \\
\text { expectation }\end{array}$ & \multicolumn{3}{|c|}{$\begin{array}{l}\text { Bundesbank Panel of } \\
\text { Household Finances (PHF) } \\
\text { 2011, 2014; GfK Consumer } \\
\text { Climate Survey 2000-2016; } \\
\text { Eurobarometer 2000-2016 }\end{array}$} & $\begin{array}{l}\text { East Germans expect higher inflation than West } \\
\text { Germans }\end{array}$ \\
\hline \multicolumn{5}{|c|}{ Political preferences } \\
\hline $\begin{array}{l}\text { Alesina and Fuchs- } \\
\text { Schündeln (2007): } \\
\text { Preferences for } \\
\text { state intervention }\end{array}$ & \multicolumn{2}{|c|}{ SOEP 1996-2002 } & $\begin{array}{l}\text { East-West } \\
\text { comparison: GDR } \\
\text { vs. FRG residents } \\
\text { before } 1990\end{array}$ & $\begin{array}{l}\text { East Germans are more in favor of state } \\
\text { intervention in social services, insurance, and } \\
\text { redistribution; stronger for older cohorts; slow } \\
\text { convergence }\end{array}$ \\
\hline $\begin{array}{l}\text { Svallfors (2010): } \\
\text { Attitudes to state } \\
\text { intervention }\end{array}$ & \multicolumn{3}{|c|}{$\begin{array}{l}\text { International So- } \\
\text { cial Survey Pro- } \\
\text { gram (ISSP), Role } \\
\text { of Government, } \\
\text { 1990, 1996, } 2006\end{array}$} & $\begin{array}{l}\text { Considerable convergence in attitudes between } \\
\text { East and West Germany: Attitudes in West } \\
\text { Germany are completely stable while attitudes in } \\
\text { the East become more similar to those in the West }\end{array}$ \\
\hline $\begin{array}{l}\text { Brosig-Koch et al. } \\
\text { (2011): Solidarity }\end{array}$ & \multicolumn{3}{|c|}{$\begin{array}{l}\text { Laboratory ex- } \\
\text { periments in Mag- } \\
\text { deburg and Essen, } \\
1995 \text { and } 2009\end{array}$} & $\begin{array}{l}\text { East Germans show consistently less fairness and } \\
\text { willingness to cooperate in solidarity games; there } \\
\text { has been no convergence in the } 20 \text { years after the } \\
\text { reunification }\end{array}$ \\
\hline $\begin{array}{l}\text { Avdeenko (2018): } \\
\text { Voting for } \\
\text { socialist party }\end{array}$ & \multicolumn{2}{|c|}{$\begin{array}{l}\text { aggregate-level: } \\
\text { panel of federal ele- } \\
\text { ction results, 1990- } \\
\text { 2013; individual- } \\
\text { level: SOEP }\end{array}$} & $\begin{array}{l}\text { Within-(former)- } \\
\text { GDR comparison } \\
\text { of border and } \\
\text { non-border areas }\end{array}$ & $\begin{array}{l}\text { Voters who lived close to inner-German border, } \\
\text { where life was harder, are less likely to lean } \\
\text { toward the successor party to East Germany's } \\
\text { communists }\end{array}$ \\
\hline $\begin{array}{l}\text { Carl (2018): } \\
\text { Attitudes toward } \\
\text { immigration }\end{array}$ & \multicolumn{2}{|c|}{ SOEP 1999-2016 } & $\begin{array}{l}\text { Duration of life } \\
\text { under } \\
\text { communism }\end{array}$ & $\begin{array}{l}\text { Concerns about immigration are stronger the } \\
\text { longer an individual has spent under communism }\end{array}$ \\
\hline \multicolumn{5}{|l|}{ Culture } \\
\hline $\begin{array}{l}\text { Rainer and Siedler } \\
\text { (2009): Social and } \\
\text { institutional trust }\end{array}$ & \multicolumn{3}{|c|}{$\begin{array}{l}\text { ALLBUS 1991, } \\
\text { 1994, } 2002\end{array}$} & $\begin{array}{l}\text { East Germans have significantly lower social trust } \\
\text { without signs of convergence; institutional trust in } \\
\text { East converges towards West }\end{array}$ \\
\hline $\begin{array}{l}\text { van Hoorn and } \\
\text { Maseland (2010): } \\
\text { Values }\end{array}$ & $\begin{array}{l}\text { SOEP } \\
1991-2006\end{array}$ & \multicolumn{2}{|c|}{$\begin{array}{l}\text { East-West differences in } \\
\text { transforming situational } \\
\text { factors into happiness }\end{array}$} & $\begin{array}{l}\text { East Germans appear to entertain values more } \\
\text { conducive to economic growth }\end{array}$ \\
\hline
\end{tabular}

(continued on next page) 
Table 3 (continued)

\begin{tabular}{|c|c|c|c|}
\hline Paper, Outcome & Data & Empirical Approach & Result \\
\hline $\begin{array}{l}\text { Bauernschuster et al. } \\
\text { (2012): Self-reliance }\end{array}$ & $\begin{array}{l}\text { ALLBUS 1991, } \\
\text { 1994, 1998, } \\
2000, \text { and } 2004\end{array}$ & East-West comparison & $\begin{array}{l}\text { East Germans show lower self-reliance } \\
\text { conditional on regional differences in } \\
\text { current economic development }\end{array}$ \\
\hline $\begin{array}{l}\text { Boenisch and } \\
\text { Schneider (2013): } \\
\text { Preferences for } \\
\text { geographic mobility }\end{array}$ & SOEP 1994 & $\begin{array}{l}\text { Eastern origin as IV } \\
\text { for club membership } \\
\text { and church attendance }\end{array}$ & $\begin{array}{l}\text { Those who grew up in the GDR are less } \\
\text { likely to be members of clubs, or to attend } \\
\text { church, which in turn relates to lower } \\
\text { geographic mobility }\end{array}$ \\
\hline $\begin{array}{l}\text { Heineck and Süssmuth } \\
\text { (2013): Trust, risk, } \\
\text { fairness, cooperation }\end{array}$ & $\begin{array}{l}\text { SOEP } 2003 \text { and } \\
2008\end{array}$ & $\begin{array}{l}\text { East-West comparison, } \\
\text { focus on convergence }\end{array}$ & $\begin{array}{l}\text { East-West convergence in risk preferences, } \\
\text { less so in trust, close to none in cooperation }\end{array}$ \\
\hline $\begin{array}{l}\text { Friehe and Mechtel } \\
\text { (2014): Conspicuous } \\
\text { consumption }\end{array}$ & $\begin{array}{l}\text { Income and ex- } \\
\text { penditure sample } \\
\text { 1993, } 2008\end{array}$ & East-West comparison & $\begin{array}{l}\text { Conspicuous consumption more important } \\
\text { in East Germany }\end{array}$ \\
\hline $\begin{array}{l}\text { Möhlmann (2014): } \\
\text { Tax morale }\end{array}$ & \multicolumn{2}{|c|}{$\begin{array}{l}\text { World Value Survey 2006; } \\
\text { European Values Survey } \\
\text { 2008; ALLBUS 2000, 2002; } \\
\text { ISSP Religion II 1998; ISSP } \\
\text { Citizenship 2004; European } \\
\text { Social Survey 2004 }\end{array}$} & $\begin{array}{l}\text { Persistent gap in tax morale and no sign of } \\
\text { quick convergence }\end{array}$ \\
\hline $\begin{array}{l}\text { Dragone and } \\
\text { Ziebarth (2017): } \\
\text { Novelty } \\
\text { consumption }\end{array}$ & $\begin{array}{l}\text { German National } \\
\text { Health Interview } \\
\text { and Examination } \\
\text { Survey } 1991 \text { and } \\
1998\end{array}$ & $\begin{array}{l}\text { Difference-in- } \\
\text { differences: East-West } \\
\text { food consumption } \\
\text { 1991-1998 }\end{array}$ & $\begin{array}{l}\text { East Germans consumed more novel } \\
\text { Western food and gained more weight than } \\
\text { West Germans when a larger variety of } \\
\text { food products became readily accessible } \\
\text { after the fall of the Wall }\end{array}$ \\
\hline $\begin{array}{l}\text { Friehe and } \\
\text { Pannenberg (2020): } \\
\text { Time preferences }\end{array}$ & $\begin{array}{l}\text { SOEP } 2008 \text { and } \\
2013\end{array}$ & $\begin{array}{l}\text { East-West comparison; } \\
\text { treatment intensity; } \\
\text { RDD around border }\end{array}$ & East Germans are less present biased \\
\hline \multicolumn{4}{|l|}{ Gender roles } \\
\hline $\begin{array}{l}\text { Bauernschuster and } \\
\text { Rainer (2012): Sex- } \\
\text { role attitudes }\end{array}$ & $\begin{array}{l}\text { ALLBUS 1980- } \\
2010 \text { (biannual) }\end{array}$ & $\begin{array}{l}\text { East-West comparison, } \\
\text { focus on convergence }\end{array}$ & $\begin{array}{l}\text { East Germans are significantly more likely } \\
\text { to hold egalitarian sex-role attitudes than } \\
\text { West Germans; no evidence of convergence }\end{array}$ \\
\hline $\begin{array}{l}\text { Fuchs-Schündeln } \\
\text { and Masella (2016): } \\
\text { Tertiary education }\end{array}$ & $\begin{array}{l}\text { Microcensus, } \\
\text { 2005-2008 }\end{array}$ & $\begin{array}{l}\text { Difference-in- } \\
\text { differences estimation }\end{array}$ & $\begin{array}{l}\text { Additional year of socialist education } \\
\text { decreases probability of college degree and } \\
\text { affects labor-market outcomes for men }\end{array}$ \\
\hline $\begin{array}{l}\text { Klüsener and } \\
\text { Goldstein (2016): } \\
\text { Extramarital fertility }\end{array}$ & $\begin{array}{l}\text { County data } \\
1878,1937,2009\end{array}$ & $\begin{array}{l}\text { East-West comparison } \\
\text { over } 140 \text { years }\end{array}$ & $\begin{array}{l}\text { Non-marital births the norm in East, but not } \\
\text { in West; difference predates } 1945 \text { division }\end{array}$ \\
\hline $\begin{array}{l}\text { Wyrwich (2017): } \\
\text { Female labor-force } \\
\text { participation }\end{array}$ & \multicolumn{2}{|c|}{$\begin{array}{ll}\text { County data 1925, } & \text { East-West } \\
\text { 1939, 1996-2015; } & \text { comparison over } \\
\text { ALLBUS 1996-2012 } & \text { nearly 100 years }\end{array}$} & $\begin{array}{l}\text { Substantial evidence of persistence in } \\
\text { female labor-force participation }\end{array}$ \\
\hline $\begin{array}{l}\text { Beblo and Görges } \\
\text { (2018): Gender gap } \\
\text { in work preferences }\end{array}$ & $\begin{array}{l}\text { ALLBUS 1991, } \\
1998 \text { and } 2012\end{array}$ & $\begin{array}{l}\text { East-West } \\
\text { comparison, focus on } \\
\text { convergence }\end{array}$ & $\begin{array}{l}\text { Substantial East-West difference in gender } \\
\text { gap in work preferences directly after } \\
\text { reunification; no convergence thereafter }\end{array}$ \\
\hline $\begin{array}{l}\text { Campa and } \\
\text { Serafinelli (2019): } \\
\text { Sex-role attitudes }\end{array}$ & $\begin{array}{l}\text { SOEP and } \\
\text { ALLBUS }\end{array}$ & $\begin{array}{l}\text { East-West comparison; } \\
\text { RDD around inner- } \\
\text { German border }\end{array}$ & $\begin{array}{l}\text { Eastern women more likely to place } \\
\text { importance on career success; East } \\
\text { Germans less likely to hold traditional } \\
\text { gender-role attitudes; effect stronger where } \\
\text { female employment growth faster }\end{array}$ \\
\hline $\begin{array}{l}\text { Lippmann et al. } \\
\text { (2020): Gender } \\
\text { norms }\end{array}$ & SOEP 1991-2012 & $\begin{array}{l}\text { Outcomes regressed on } \\
\text { dummy for wife higher } \\
\text { earner, interacted with } \\
\text { East Germany dummy }\end{array}$ & $\begin{array}{l}\text { More equal breadwinner norm in East: } \\
\text { women can earn more than their husband } \\
\text { without having to increase housework } \\
\text { hours, put their marriage at risk, or } \\
\text { withdraw from labor market }\end{array}$ \\
\hline $\begin{array}{l}\text { Lippmann and Senik } \\
\text { (2018): Math scores }\end{array}$ & PISA-E, SOEP & East-West comparison & $\begin{array}{l}\text { Gender gap in math achievement is lower } \\
\text { in former GDR }\end{array}$ \\
\hline
\end{tabular}

Notes: Authors' own elaboration based on literature survey. See main text for more detailed discussion. 
Table A1: East-West Differences before World War II: Additional Outcomes

\begin{tabular}{|c|c|c|c|c|}
\hline & \multirow{2}{*}{$\begin{array}{c}\text { Full German } \\
\text { sample }\end{array}$} & \multicolumn{3}{|c|}{ Band around the East-West border } \\
\hline & & $<=200 \mathrm{~km}$ & $<=100 \mathrm{~km}$ & Border counties \\
\hline \multicolumn{5}{|c|}{ Economic outcomes } \\
\hline \multicolumn{5}{|c|}{ Agricultural employment share (1925) } \\
\hline Constant (West) & $\begin{array}{c}0.352^{* * *} \\
(0.009)\end{array}$ & $\begin{array}{c}0.382^{* * *} \\
(0.012)\end{array}$ & $\begin{array}{c}0.357^{* * *} \\
(0.018)\end{array}$ & $\begin{array}{c}0.406^{* * *} \\
(0.033)\end{array}$ \\
\hline GDR & $\begin{array}{c}-0.128^{* * *} \\
(0.015)\end{array}$ & $\begin{array}{c}-0.165^{* * *} \\
(0.019)\end{array}$ & $\begin{array}{c}-0.138^{* * *} \\
(0.026)\end{array}$ & $\begin{array}{l}-0.051 \\
(0.043)\end{array}$ \\
\hline \multicolumn{5}{|c|}{ Health sector employment share (1925) } \\
\hline Constant (West) & $\begin{array}{l}0.013^{* * *} \\
(0.000)\end{array}$ & $\begin{array}{c}0.012^{* * *} \\
(0.001)\end{array}$ & $\begin{array}{c}0.012^{* * *} \\
(0.001)\end{array}$ & $\begin{array}{c}0.009^{* * *} \\
(0.001)\end{array}$ \\
\hline GDR & $\begin{array}{c}0.001 \\
(0.001)\end{array}$ & $\begin{array}{c}0.001 \\
(0.001)\end{array}$ & $\begin{array}{c}0.000 \\
(0.001)\end{array}$ & $\begin{array}{c}0.001 \\
(0.001)\end{array}$ \\
\hline \multicolumn{5}{|c|}{ Political preferences } \\
\hline \multicolumn{5}{|c|}{ SPD vote share (1924) } \\
\hline Constant (West) & $\begin{array}{l}0.201^{* * *} \\
(0.005)\end{array}$ & $\begin{array}{l}0.234^{* * *} \\
(0.007)\end{array}$ & $\begin{array}{c}0.268^{* * *} \\
(0.010)\end{array}$ & $\begin{array}{c}0.277^{* * *} \\
(0.025)\end{array}$ \\
\hline GDR & $\begin{array}{l}0.104^{* * *} \\
(0.008)\end{array}$ & $\begin{array}{l}0.070^{* * *} \\
(0.011)\end{array}$ & $\begin{array}{l}0.034^{* *} \\
(0.015)\end{array}$ & $\begin{array}{c}0.010 \\
(0.034)\end{array}$ \\
\hline \multicolumn{5}{|c|}{ Zentrum+BVP vote share (1924) } \\
\hline Constant (West) & $\begin{array}{c}0.363^{* * *} \\
(0.010)\end{array}$ & $\begin{array}{c}0.310^{* * *} \\
(0.014)\end{array}$ & $\begin{array}{c}0.258^{* * *} \\
(0.020)\end{array}$ & $\begin{array}{l}0.240^{* * *} \\
(0.041)\end{array}$ \\
\hline GDR & $\begin{array}{c}-0.320^{* * *} \\
(0.012)\end{array}$ & $\begin{array}{c}-0.258^{* * *} \\
(0.017)\end{array}$ & $\begin{array}{c}-0.184^{* * *} \\
(0.024)\end{array}$ & $\begin{array}{l}-0.086 \\
(0.058)\end{array}$ \\
\hline \multicolumn{5}{|c|}{ DNVP vote share (1924) } \\
\hline Constant (West) & $\begin{array}{l}0.148^{* * *} \\
(0.005)\end{array}$ & $\begin{array}{l}0.191^{* * *} \\
(0.008)\end{array}$ & $\begin{array}{c}0.220^{* * *} \\
(0.012)\end{array}$ & $\begin{array}{c}0.229^{* * *} \\
(0.017)\end{array}$ \\
\hline GDR & $\begin{array}{l}0.104^{* * *} \\
(0.010)\end{array}$ & $\begin{array}{c}0.039^{* * *} \\
(0.012)\end{array}$ & $\begin{array}{l}-0.011 \\
(0.016)\end{array}$ & $\begin{array}{c}0.011 \\
(0.034)\end{array}$ \\
\hline \multicolumn{5}{|l|}{ Voter turnout (1924) } \\
\hline Constant (West) & $\begin{array}{c}0.776^{* * *} \\
(0.003)\end{array}$ & $\begin{array}{c}0.800^{* * *} \\
(0.004)\end{array}$ & $\begin{array}{c}0.825^{* * *} \\
(0.004)\end{array}$ & $\begin{array}{c}0.822^{* * *} \\
(0.008)\end{array}$ \\
\hline GDR & $\begin{array}{l}0.051^{* * *} \\
(0.004)\end{array}$ & $\begin{array}{c}0.032^{* * *} \\
(0.005)\end{array}$ & $\begin{array}{c}0.005 \\
(0.007)\end{array}$ & $\begin{array}{l}-0.018 \\
(0.012)\end{array}$ \\
\hline \multicolumn{5}{|l|}{ Culture } \\
\hline \multicolumn{5}{|l|}{ Catholic share (1925) } \\
\hline Constant (West) & $\begin{array}{c}0.491^{* * *} \\
(0.015)\end{array}$ & $\begin{array}{c}0.380^{* * *} \\
(0.022)\end{array}$ & $\begin{array}{c}0.317^{* * *} \\
(0.029)\end{array}$ & $\begin{array}{c}0.226^{* * *} \\
(0.052)\end{array}$ \\
\hline GDR & $\begin{array}{c}-0.438^{* * *} \\
(0.017)\end{array}$ & $\begin{array}{c}-0.326^{* * *} \\
(0.023)\end{array}$ & $\begin{array}{c}-0.255^{* * *} \\
(0.032)\end{array}$ & $\begin{array}{l}-0.094 \\
(0.069)\end{array}$ \\
\hline \multicolumn{5}{|l|}{ Jewish share (1910) } \\
\hline Constant (West) & $\begin{array}{c}0.005^{* * *} \\
(0.000)\end{array}$ & $\begin{array}{l}0.006^{* * *} \\
(0.000)\end{array}$ & $\begin{array}{c}0.007^{* * *} \\
(0.001)\end{array}$ & $\begin{array}{l}0.005^{* * *} \\
(0.001)\end{array}$ \\
\hline GDR & $\begin{array}{c}-0.003^{* * *} \\
(0.000)\end{array}$ & $\begin{array}{c}-0.004^{* * *} \\
(0.001)\end{array}$ & $\begin{array}{c}-0.005^{* * *} \\
(0.001)\end{array}$ & $\begin{array}{c}-0.004^{* * *} \\
(0.001)\end{array}$ \\
\hline
\end{tabular}

Notes: Each pair of “GDR” and “Constant (West)” estimates reflect the result of a separate regression. Countylevel analyses. Distance to border based on county centroids. Robust standard errors in parentheses: significance at ${ }^{*} 10,{ }^{* *} 5,{ }^{* * *} 1$ percent. Data source: Falter and Hänisch (1990). 
Figure A1: Spotting the GDR Before It Existed: Economic Outcomes

Manufacturing employment share (1925)

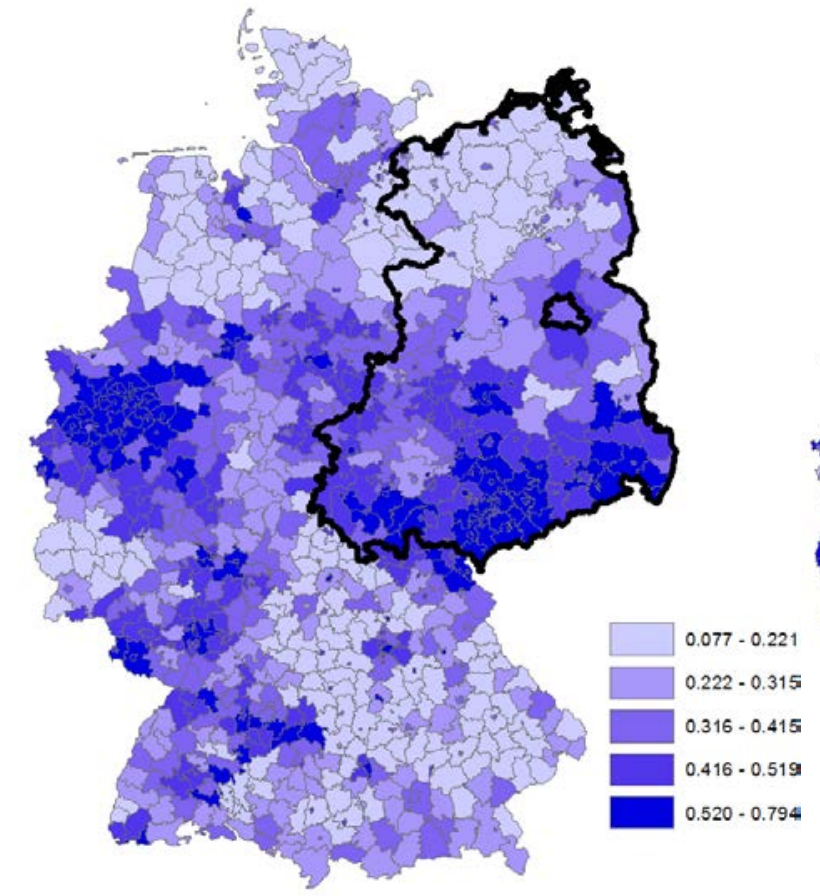

\section{Self-employment share (1925)}

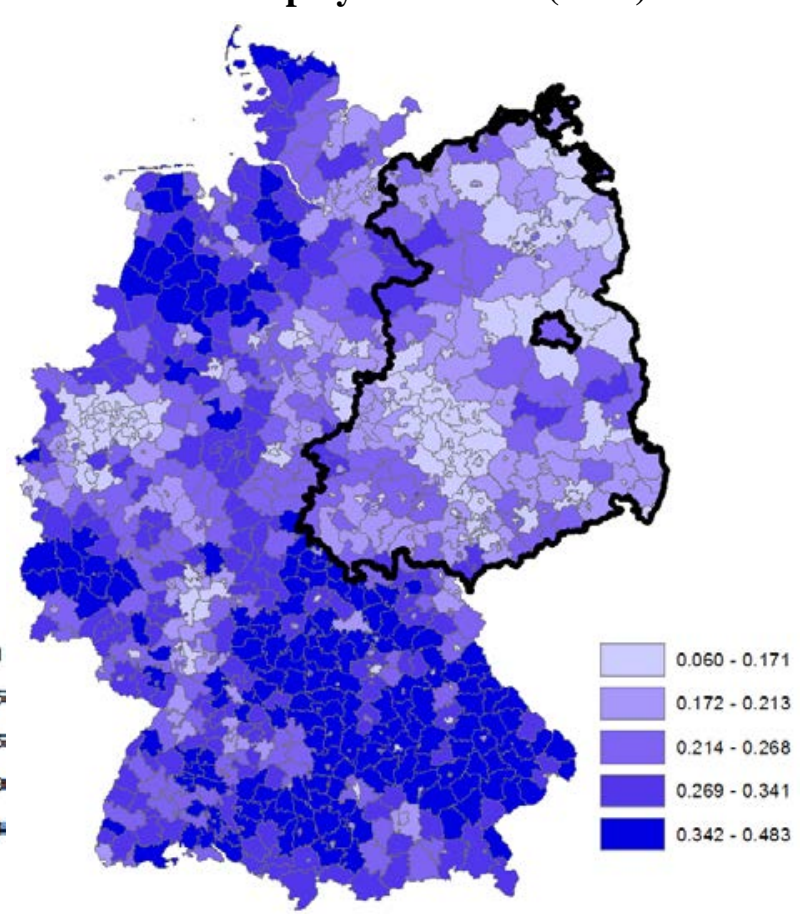

Notes: Colors refer to quintiles on each variable. Missing data imputed by nearest neighbor. Source: Own depiction based on county-level census data in Falter and Hänisch (1990).

Figure A2: Spotting the GDR Before It Existed: Political Preferences

\section{Communist (KPD) vote share (1924)}

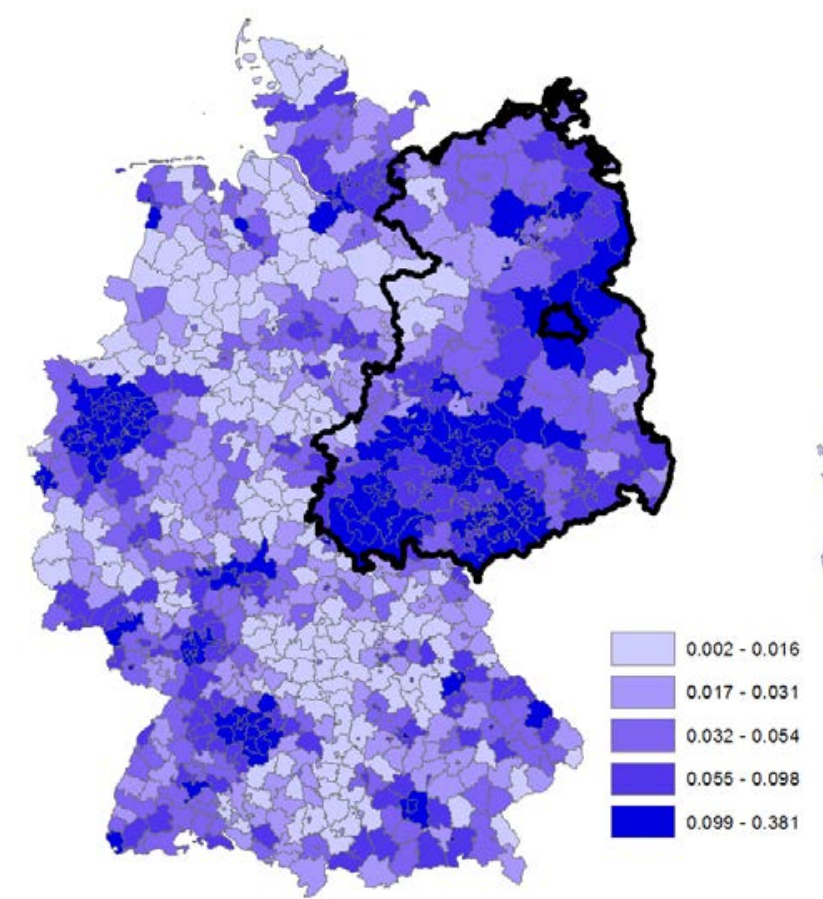

Left-party vote share (1924)

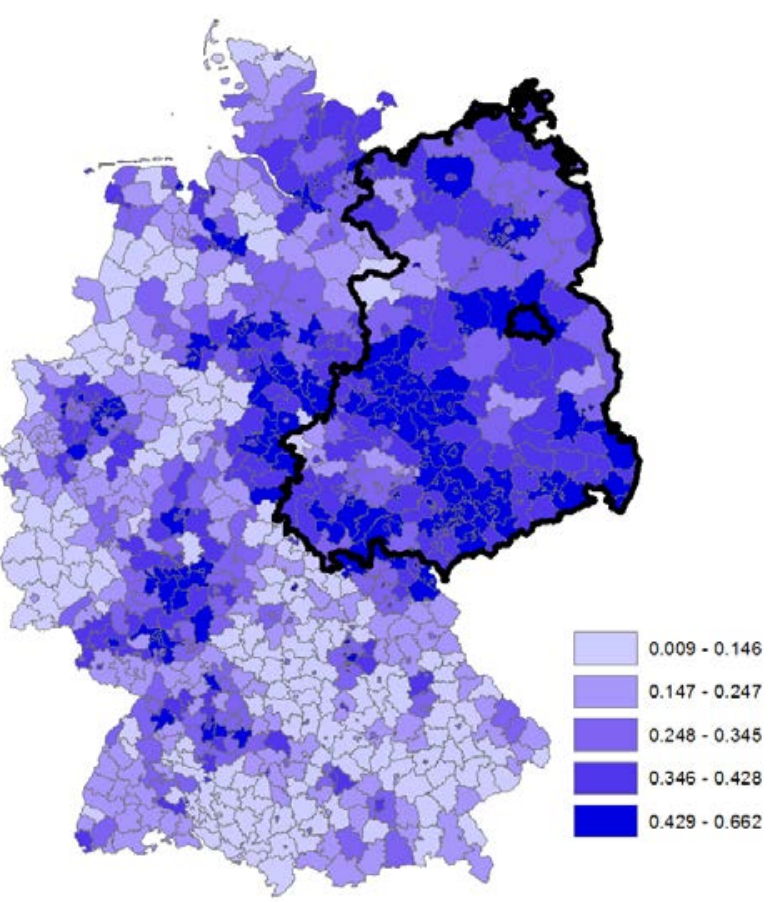

Notes: Left parties include KPD, SPD, and USPD. Colors refer to quintiles on each variable. Missing data imputed by nearest neighbor. Source: Own depiction based on county-level data of Reichstag election in December 1924 in Falter and Hänisch (1990). 
Figure A3: Spotting the GDR Before It Existed: Culture

Protestant share (1925)

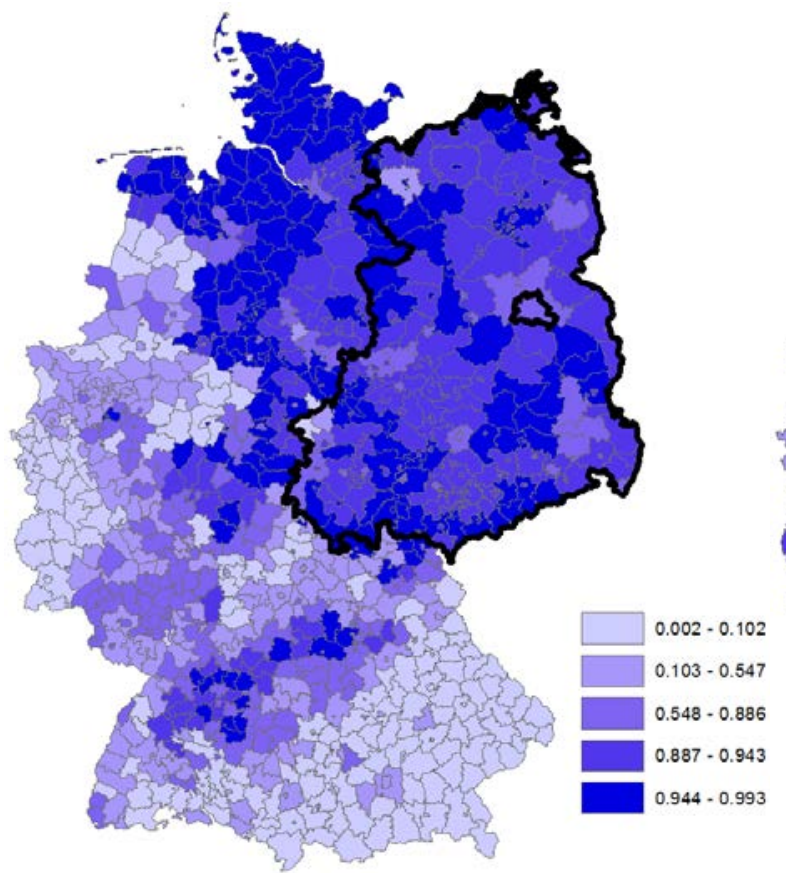

Church attendance (1900-1910)

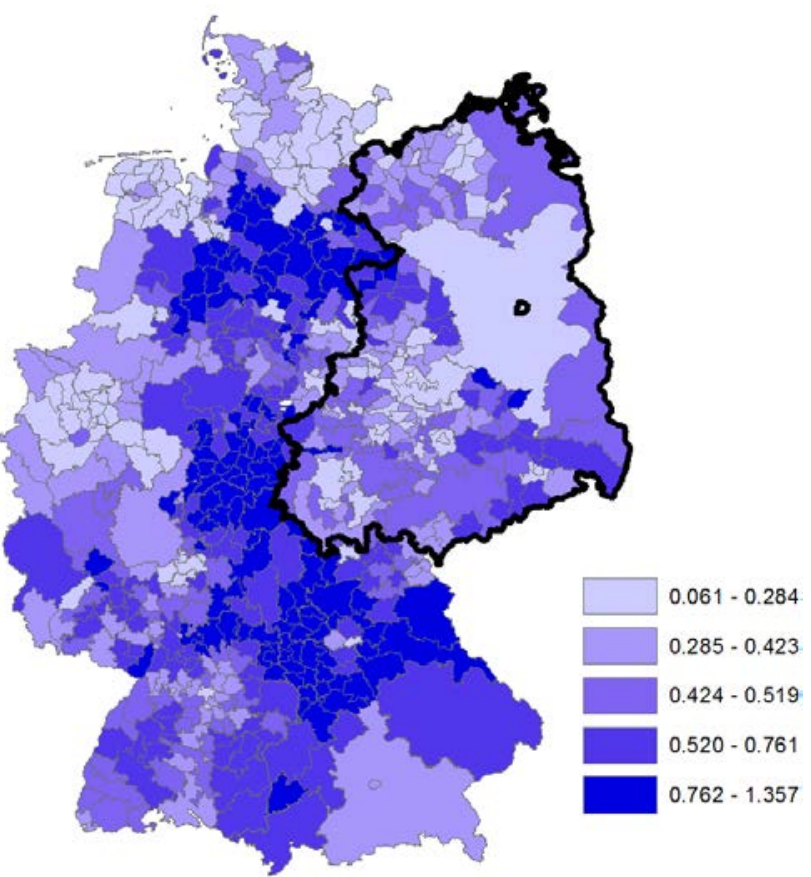

Notes: Colors refer to quintiles on each variable. Missing data imputed by nearest neighbor. Source: Own depiction based on census data at the county level in Falter and Hänisch (1990) and Protestant church attendance data at the church-district level in Hölscher (2001).

\section{Figure A4: Spotting the GDR Before It Existed: Gender Roles}

\section{Female labor-force participation (1925)}

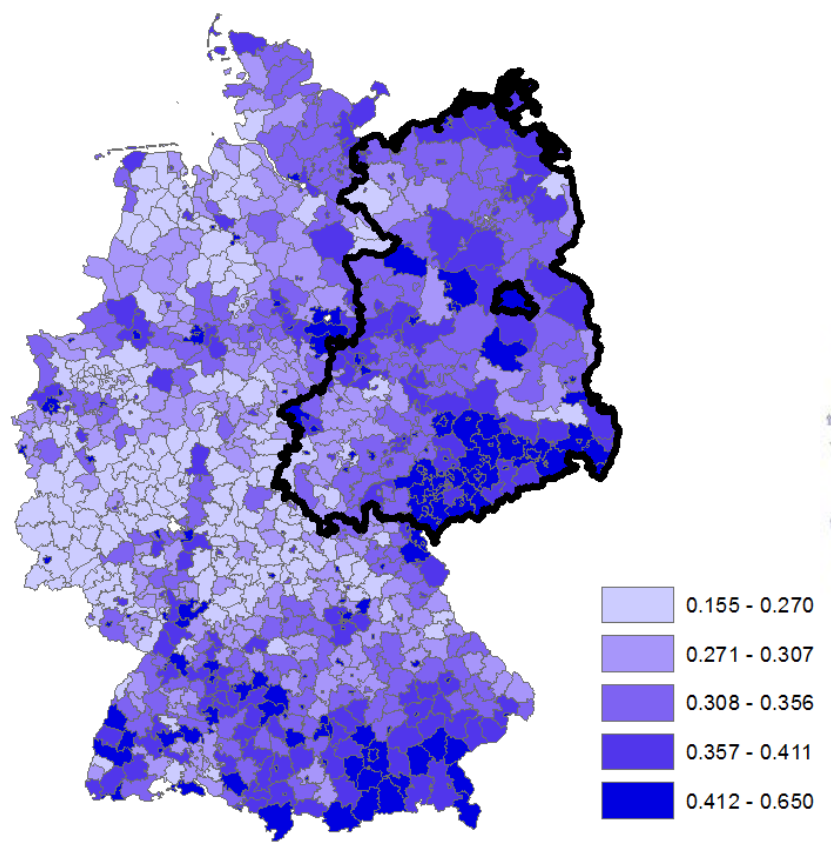

Extramarital birth ratio (1937)

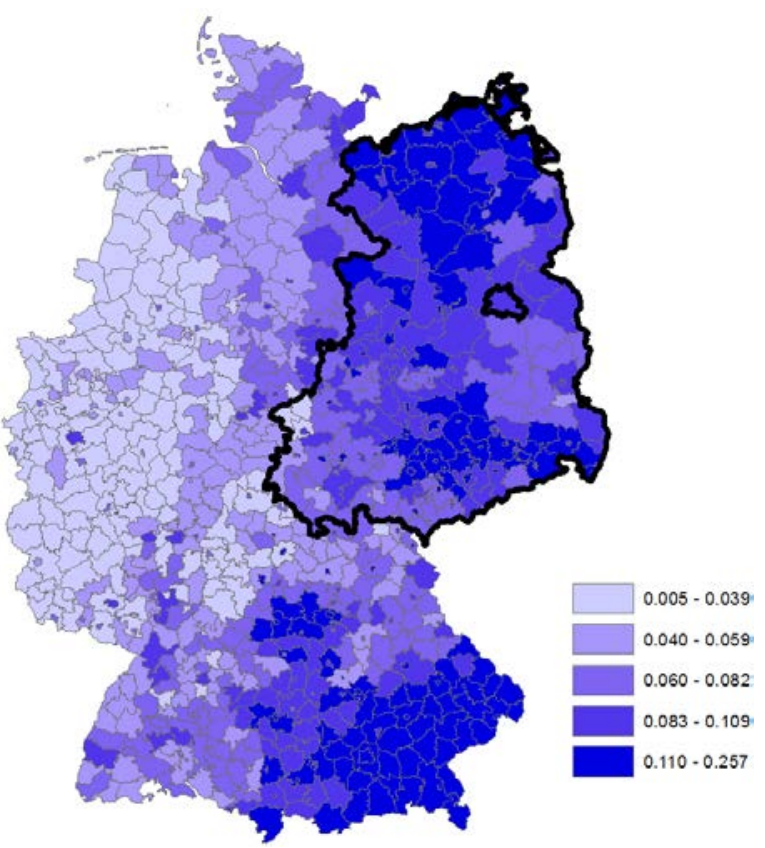

Notes: Colors refer to quintiles on each variable. Missing data imputed by nearest neighbor. Source: Own depiction based on county-level data on female labor-force participation provided by Wyrwich (2019) and extramarital birth ratio provided by Klüsener and Goldstein (2016). 